\title{
Do corporations have a duty to be trustworthy?
}

\author{
NIKOLAS KIRBY, ANDREW KIRTON \\ and AISLING CREAN
}

Abstract: Since the global financial crisis in 2008, corporations have faced a crisis of trust, with growing sentiment against 'elites and 'big business' and a feeling that 'something ought to be done' to re-establish public regard for corporations. Trust and trustworthiness are deeply moral significant. They provide the 'glue or lubricant' that begets reciprocity, decreases risk, secures dignity and respect, and safeguards against the subordination of the powerless to the powerful. However, in deciding how to restore trust, it is difficult to determine precisely what should be done, by whom, and who will bear the cost, especially if any action involves a risk to overall market efficiency and corporate profitability.

The paper explores whether corporations have a moral duty to be trustworthy, to bear the cost of being so and thus contribute to resolving the current crisis of trust. It also considers where the state and other social actors have strong reason to protect and enforce such moral rights, while acknowledging that other actors have similar obligations to be trustworthy. It outlines five 'salient factors' that trigger specific rights to trustworthiness and a concomitant duty on corporations to be trustworthy: market power, subordination (threat and intimidation), the absence of choice, the need to preserve systemic trust, and corporate political power which might undermine a state's legitimacy. Absent these factors and corporations do not have a general duty to be trustworthy, since a responsible actor in fair market conditions should be able to choose between the costs and benefits of dealing with generally trustworthy corporations.

Keywords: Trust, organisational trust, institutional trust, trustworthiness, corporate trust, corporate trustworthiness, business ethics.

\section{EXECUTIVE SUMMARY}

Since the global financial crisis in 2008, corporations have faced a crisis of trust, with growing sentiment against 'elites and 'big business' and a feeling that 'something ought to be done' to re-establish public regard for corporations. Trust and trustworthiness 
are deeply morally significant. They provide the 'glue or lubricant' that begets reciprocity, decreases risk, secures dignity and respect, and safeguards against the subordination of the powerless to the powerful. However, in deciding how to restore trust, it is difficult to determine precisely what should be done, by whom, and who will bear the cost, especially if any action involves a risk to overall market efficiency and corporate profitability.

The paper explores whether corporations have a moral duty to be trustworthy, to bear the cost of being so and thus contribute to resolving the current crisis of trust. It also considers where the state and other social actors have strong reason to protect and enforce such moral rights, while acknowledging that other actors have similar obligations to be trustworthy.

The authors outline five 'salient factors' that trigger specific rights to trustworthiness and a concomitant duty on corporations to be trustworthy: market power, subordination (threat and intimidation), the absence of choice, the need to preserve systemic trust, and corporate political power which might undermine a state's legitimacy. Without these factors, corporations do not have a general duty to be trustworthy, since a responsible actor in fair market conditions should be able to choose between the costs and benefits of dealing with generally trustworthy corporations.

A trustworthy corporation is defined as one with a robust disposition to fulfil its commitments to another, providing rational grounds for that other to rely on. A commitment (implicit or explicit) involves an overriding obligation to act or not act. It transcends, for example, corporate aims, including profit, and offers accountability (remedy, compensation, etc.) if the obligation is not met.

The author notes that commitments may or may not be enforceable, and not all breaches undermine trustworthiness of a corporation, which may breach for reasons of self-defence, for example. Corporations might also face conflicting commitments, raising the difficult moral question of prioritisation.

Trustworthiness involves reliance, or not adopting contingencies against risk, resulting in vulnerability to an unfulfilled commitment. Being worthy of reliance means how the corporation is structured, resourced, incentivised, and motivated, and, crucially, may be very costly to the corporation. Making commitments that were implicit explicit, and allowing others to make your commitments enforceable are two ways of demonstrating reliability.

External measures, derived from agents such as the state, professional bodies, unions, or consumer groups, may make internal measures more reliable. Reputation, which can be enhanced or damaged by other corporations in the same sector, is another source of evidence of reliability. Likewise, people may trust systems, groups, or societies because of the qualities of one individual. 
The authors note a widespread desire, partly born of legitimate frustration and injustice, to 'take back control' and restore trust in corporations. That will involve both controlling measures, such as regulation, vigilance, and threat or punishment, and also measures to instil values, culture, and purpose to corporations, increasing the social capital and rewards for trustworthy behaviour and structuring markets in a way that avoids a 'race to the bottom'. To rebuild trust, we must distribute the duties to make it happen and the responsibilities to bear its cost.

\section{INTRODUCTION}

Since the Global Financial Crisis (GFC) in 2008, there has been a broad view that corporations are facing a 'crisis of trust'. ${ }^{1}$ It is has been 'one of the main casualties of the excesses of capitalism;'2 and 'taken a battering'. ${ }^{3}$ According to the Edelman Trust Barometer, it remains at a record low. ${ }^{4}$ This crisis has not merely had direct negative economic impacts, ${ }^{5}$ but is also thought to be contributing to the broader destabilisation of many political economies, seemingly legitimising populist and reactionary sentiment against 'elites' and 'big business'. ${ }^{6}$

Given this putative crisis, therefore, there is a feeling that something specifically about trust and trustworthiness simply 'ought to be done'. Indeed, it seems that, if we are to re-design the future of corporations, then we must address the crisis of trust with respect to them, or their future might be quite limited.

However, it is one thing to believe that something ought to be done, and another to determine what precisely ought to be done, who ought to do it, and who in particular should bear the cost. After all, acting to resolve some aspects of this crisis of trust may be individually — and socially — quite costly. It may compromise profits. It may even compromise overall market efficiency.

\footnotetext{
${ }^{1}$ See Parker (2017). The 'crisis of trust' has been ongoing since prior to the GFC. See Dennis Thompson (2005: 248) for some great headlines, and the 'need to restore trust'. See also Bishop (2017) and Mayer (forthcoming: 7-8).

${ }^{2}$ Christine Lagarde says trust has been one the main casualties of excesses of capitalism, and that we need a shift toward greater integrity and accountability (Lagarde 2014). Mark Carney says that institutions need to take greater responsibility (Carney 2013).

${ }^{3}$ Parker (2017: 19).

${ }^{4}$ Parker (2017: 19).

${ }^{5}$ See Edey (2009) and Moore \& Mirzaei (2014).

${ }^{6}$ In 2016, the current UK government's environment secretary Michael Gove infamously stated: 'Unelected, unaccountable elites, I'm afraid it's time to say, "You're fired: We are going to take back control"' (Cooper 2016).
} 
This essay explores when, if ever, corporations have a moral duty to be trustworthy (rather than necessarily a legal one); to bear the cost of such trustworthiness; and hence to play a part in resolving this crisis. Such a duty will not only reflect when other parties have a moral right to deal with trustworthy corporations, but also where the state and other social actors have strong reason to protect such rights and enforce such a duty through laws and other incentives. ${ }^{7}$

In focusing upon the moral duty of corporations in particular, to be trustworthy, we do not deny that other actors may also have similar obligations to be trustworthy. ${ }^{8}$ A fuller account of how to resolve the 'crisis of trust' would explore the interactions between all of these duties.

This paper argues that corporations do not have a general moral duty to be trustworthy. In other words, it is not true that corporations have a duty to be trustworthy merely because others may be vulnerable with respect to them breaching a commitment. In short, this is because a responsible actor in fair market conditions should be able to choose between the costs and benefits of dealing with more or less trustworthy corporations. However, there are at least five different salient factors that can trigger more specific 'rights to trustworthiness' and a concomitant duty on corporations

\footnotetext{
${ }^{7}$ Although, this is not to say that other parties might not also have important obligations (that is, in resetting legitimate expectations). However, it is the place of governments to solve coordination and misinformation problems.

${ }^{8}$ As many business leaders have noted in the preparation of this paper, no doubt some of the responsibility for distrust lies in unreasonable expectations being placed upon corporations by other actors; attributing to them commitments that they cannot reasonably be expected to have. For example, a $2015 \mathrm{KPMG}$ report on digital banking observed that customers were now hyper-demanding and had unreasonable expectations (Roberts 2015). As such, those actors may hold part of the responsibility to correct these expectations. Nor do we deny that such other actors, and corporations may have other duties to create and sustain conditions of social trust. It could be argued, however, that the reason why some business leaders hold the position that stakeholders should correct their unreasonable expectations, is because they are selecting 'evidence that affirms their own world view' (Wheatley 2015). In other words, it may be that some business leaders believe that stakeholders hold unreasonable expectations of business, because those leaders are susceptible to psychological biases, which incline them to place blame elsewhere. But note that, while such biases may be a reason why some or even many business leaders hold that view, it does not follow that it is untrue that stakeholders sometimes hold unreasonable expectations of business. Of course, there will no doubt be murky cases where it is difficult to determine decisively whether a corporation had a commitment to a stakeholder. But, there will also be cases where it is wrong to call what the corporation did (or failed to do) an actual betrayal, simply on the basis that the stakeholder felt betrayed. If the corporation never gave any indication it would do what the stakeholder relied on it doing, and the corporation could not be expected to recognise - and then forewarn against - reliance upon it, then the corporation cannot be held accountable for failing to fulfil that reliance (in other words, we could not take it to have an implicit commitment: see below Section 2.1. A type of case where corporations can be held accountable in this way is estoppel cases, which are discussed below (83). In this type of case, the corporation is partly responsible for the stakeholder's reliance upon it, and should have recognised and forewarned against it.
} 
to be trustworthy, along with good reason for state intervention to enforce it. ${ }^{9}$ These five factors are: market power, subordination, the absence of choice, the need to preserve systemic trust, and corporate political power. So, corporations have no general moral duty to be trustworthy to whoever deals with them. But they do have specific duties to be trustworthy to different parties, in these five circumstances.

One final introductory note: when writing about trust, it is normal to begin by highlighting the central role that trust plays in any form of fruitful human activity (for instance, using language). The observation that trust is of fundamental value in our lives is no less true of trust in the world of business. Without any degree of trust toward (and within) the business world, fruitful exchange is made impossible.

But in addressing the crisis of trust, it is not enough to just increase trust in the corporate world. After all, trust can be misplaced. What is more important than simply increasing trust in the corporate world is increasing well-founded trust. One could aim to increase trust in the corporate world for self-interested purposes, on the basis that trust in corporations is something instrumentally useful to those who stand to gain from it. But this would not address the causes of the distrust, and would just prop up an unhealthy system.

Therefore, to properly address the crisis of trust, trustworthiness in the corporate world must be increased. But, then, we immediately encounter the question of whose shoulders carry this burden, and whether it is the corporation itself that carries it. We must ask whether there are circumstances in which corporations should be held to higher standards of trustworthiness than 'the morals of the marketplace' would suggest. ${ }^{10}$ This is why the central goal of this essay is to answer whether corporations themselves have moral duties to be trustworthy, rather than to make a case for the instrumental or functional value of trust in the world of corporate governance. Addressing that concern leaves open the question of who should increase that trust, and also leaves open the possibility that any trust in that world is unwise. ${ }^{11}$

This paper is in four parts. First, it defines trustworthiness in terms of its four key components. Secondly, it sets out five distinct values that a right to trustworthiness might protect. Thirdly, it contrasts the utilitarian case for increasing trustworthiness with a case based on rights, but rejects the idea of a general right to trustworthiness. Finally, it lays out five salient factors that do, as exceptions, ground specific rights.

\footnotetext{
${ }^{9}$ These exceptions count as cases where fair (idealised) market conditions do not hold, for various reasons. ${ }^{10}$ Thanks to an anonymous reviewer for this helpful phrasing, which comes from a US Corporate Law case: Meinhard v. Salmon, 164 N.E. 545 (N.Y. 1928). In this case, Justice Cardozo had to decide whether a partner/joint venture would be held to 'the morals of the market place' or be subject to more stringent legal duties.

${ }^{11}$ Section 3 considers the moral value of trustworthiness in the business world, in more depth. But, it also begins with some of the classic widely repeated statements by key thinkers on the instrumental or functional value of trust; namely, that it is essential in enabling human cooperation and morally valuable activity.
} 


\section{WHAT DOES IT MEAN FOR A CORPORATION TO BE TRUSTWORTHY?}

A corporation is trustworthy, if and only if it is worthy of another's trust. More specifically, in this paper, we shall mean that a corporation is trustworthy, if and only if, it has a robust disposition to fulfil its commitments to another; and provides rational grounds to that other to rely upon it to do so. ${ }^{12}$ In this section, we shall explain each component of this definition in turn. First, the meaning of 'commitment' and what varieties of commitment there are; secondly 'fulfilment' and its opposite 'breach'; thirdly, 'reliance'; fourthly, what might constitute 'a robust disposition'; and, finally, what might constitute 'rational grounds' for reliance.

\subsection{Commitment}

Corporations are trusted and distrusted with respect to their commitments. ${ }^{13}$ At its core, a commitment creates an obligation to another agent to perform some action (or refrain from some action). An 'obligation' is an overriding reason to act (or not), in

\footnotetext{
${ }^{12}$ It might be argued that this definition of trustworthiness does not correspond to all uses of the word 'trust'. This definition, though, is being used to pick out an important form of trust in the context of corporations. So, even if this is not trust per se, it is the form of trust most relevant to this article.

On terminology: 'corporation' is used for the majority this article. This refers to what 'company', 'business', 'firm', etc. sometimes also refer to. Organisations and institutions are a more general type of structured collective entity, to which these belong.

In philosophy, organisations are often called groups (Fricker 2009, List \& Pettit 2011, Mathieson 2006, Schmitt 1994, Tollefsen 2006) or sometimes collectives (Collins 2013) or group agents (List \& Pettit 2011). In management, they are referred to as organisations (Kramer 2006). In social sciences more broadly, the terminology varies. Sztompka (1998) uses 'institutions' to refer to legal, political, public sector bodies, and refers to organisations too. In sociology, 'institution' and 'institutional trust' often refer to embedded/established social practices, or conventions (Granovetter 1973, 1985, Möllering 2005, Rousseau et al. 1998: 396, Shapiro 1987, Zucker 1986).

${ }^{13}$ This article adopts Katherine Hawley's (2014: 10) 'commitment' view of trust and distrust, which says that to trust is to rely on someone to meet a commitment, and to distrust is to not rely on them to meet a commitment. There are other views on what trusting reliance is (e.g., Baier 1986: 234-5): reliance on another's goodwill; Holton (1994: 66): reliance from a concern for the regard they hold you in; Jones (1996: 4): reliance from an attitude of optimism about them). Hawley's view is most plausible as applied to trust in corporations, and also captures when it is appropriate to trust: when a commitment is in place. The appropriateness of trust is key for defining trustworthiness. Hollis (1998: 11) and Nickel (2007) give similar accounts to Hawley, but they take obligation rather than commitment as central. The commitment view rather than an obligation view is adopted because it helpfully makes clear the distinction between the obligations we gain through explicit and implicit means. On whether it is appropriate to think of corporations as having commitments: Gilbert (1996, 2006, and 2013) argues that groups can make commitments. Fricker (2012) draws on Gilbert's work to argue that institutional members make (initially to one another) commitments to be jointly trustworthy.
} 
the sense that it overrides other reasons to act in contrary ways. ${ }^{14}$ Hence, unlike merely stating a corporate aspiration, aim, or prediction; a genuine commitment generates a reason to act that overrides subsequent countervailing reasons, such as self-interestedly maximising profit. In this way, commitments are demanding of corporations. However, their fulfilment can also be rightfully demanded because they must be owed to another agent. This means that the other agent can hold the corporation rightfully accountable if it does not fulfil the obligations: seeking remedy, compensation, damages, or at least an apology. ${ }^{15}$

However, although all commitments are obligations, not all obligations are commitments. Commitments are obligations which an agent acquires either via consent or the legitimate expectations of others given the circumstances. ${ }^{16}$

Corporations can have different types of commitments. In particular, they can be explicit or implicit; and legally enforceable or legally unenforceable.

First, a corporation acquires an explicit commitment if it promises or otherwise expressly binds itself to do something. In 2017, for example, Amazon, Twitter, Target, and Nike (among others) put their names to a pledge to help reduce American carbon emissions by 26 per cent by 2025 (The Economist 2017). ${ }^{17}$ Corporations can acquire implicit commitments due to the roles they take on or function they perform in society. ${ }^{18}$ For example, Facebook takes on an implicit commitment to protect the privacy of its users, by inviting users to rely on Facebook to safely store data on their

\footnotetext{
${ }^{14} \operatorname{Raz}(1975)$.

${ }^{15}$ To be owed something is to have certain normative powers with respect to the duty that another perform an action, including the power to release from that duty (see Owens 2006, 2012). For a corporation to be obligated in this way allows others to legitimately hold reactive attitudes such as blame and betrayal toward it, in case it fails to fulfil the obligation. On the connection between holding agents as morally responsible, and holding reactive attitudes toward them, see Darwall (2009), Strawson (1962), and Wallace (2006).

${ }^{16}$ Hawley (2014: 11) says that commitments can be gained by 'roles and external circumstances' and via 'mutual expectation and convention'. There is something necessarily willful about commitments, that is not necessarily the case with obligations. One can always, at some point in the past, have avoided even an implicit commitment, or disclaimed it before it crystallised. Obligations, by contrast, can be mandatory and 'natural'. Hence, for example, we may normally acquire an implicit commitment to follow the law (which will also be a moral obligation if legitimate) in a particular country by acting in a way that invites reliance upon that fact. However, we could have disclaimed that we were going to follow the law, perhaps even indicating our intention to break it. Regardless of the implications of that, we would not be breaking a commitment, and hence would not necessarily be compromising our trustworthiness. Similarly, a mafia boss who explicitly disclaims her intention to comply with the law, and acts criminally may theoretically still be trustworthy, so long as she lives up to all her commitments (nefarious or otherwise) and avoids acquiring other implicit commitments.

${ }^{17}$ See also Citigroup's 'Our promise to our customers' (Dinsmore 2014).

${ }^{18}$ See footnote 13 .
} 
servers, as a consequence of making use of the platform. ${ }^{19}$ This illustrates how corporations can give others the right to hold them accountable for certain things, without explicitly committing to those things. ${ }^{20}$

In addition to explicit and implicit commitments, there is a further distinction between legally enforceable and legally unenforceable commitments. The distinction tells us whether a corporation can be forced to carry out the commitment by law. ${ }^{21}$

The paradigm of legally enforceable explicit commitment is contract. ${ }^{22}$ Unenforceable explicit commitments on the other hand are those the corporation avows, but where legal mechanisms will not ensure fulfilment. ${ }^{23}$ To illustrate: Allied Chemical Corporation (ACC) produced a profitable pesticide called Kepone. It contracted with outside producers to supplement supplies. One producer manufactured Kepone under terrible working conditions, resulting in serious damage to the health of the workers and others in the vicinity. ACC had no legal duty to take responsibility for the health of the workers of its subcontractors, so it could not be enforced that they do so. Furthermore, ACC initially denied having any moral duty to the health of these workers. Later, however, the head of Speciality Chemicals at ACC (Richard Wagner) said that ACC would recognise its moral obligation to such workers. ACC thereby made an explicit commitment to workers who were beyond its legal commit-

\footnotetext{
${ }^{19}$ Facebook will have had such implicit commitments to protect user privacy, even if its terms and conditions explicitly stated data would be shared with third parties that could then use it for dubious purposes. Corporations cannot absolve these implicit commitments by, for example, putting the burden on users of 'opting out' of sharing or making opaque how exactly data are shared so putting the burden on users to understand, when it can be assumed that being made aware would cause a significant number of users to opt out. Recent GDPR (General Data Protection Regulation) compliance guidelines have made such implicit commitments enforceable.

${ }^{20}$ Accounts of how promises obligate can shed light on implicit commitment. Several authors argue that promissory obligation is a matter of having invited another's reliance, or recognised and then not disinvited that reliance, on one's performance of some action (e.g., Friedrich \& Southwood 2011, Pink 2009, Scanlon 1990, Thomson 1990). To incur promissory obligation, then, does not require an explicit assertion of 'I promise to $x$ ', because by repeat fulfilment of reliance, where it is reasonable for the other party to assume that reliance has been recognised, one incurs the obligation. Black (2004: 274) also suggests reliance begins to plausibly ground an obligation to perform an act, once it looks like you have caused another to rely on you performing that act. See also page 83 below on the related estoppel legal device. ${ }^{21}$ Being legal usually entails being a commitment (explicit but usually implicit). It might not if a company or another agent were to explicitly disavow the law (for example, declaring it to be unjust, or inefficient), or where the community for some exceptional reason would not see compliance as expected or required (for example, where the state had collapsed or in circumstances that should reasonably justify the belief that people are not necessarily committed to the nominal law.)

${ }^{22}$ Putting aside the exceptional cases of 'unenforceable contracts' (see Richardson 2011).

${ }^{23}$ The law could be changed to ensure compliance in future. Sometimes it will in principle be impossible to ensure the action is carried out, in cases where breaches of commitment result in irreplaceable losses. But penalties may be enforceable.
} 
ments. ${ }^{24}$ This case thus reflects the difference between the legal and moral duties a corporation may have: ACC had no legal duties to protect the health of subcontracted workers, but did recognise a moral duty to protect it. ${ }^{25}$ It also illustrates the relationship between moral/legal duties and commitments: one can have either form of duty without a corresponding explicitly commitment. But, one will have implicit commitments to uphold those duties.

Implicit commitments can also be enforceable or unenforceable. For example, an agent may be implicitly committed to comply with local laws, but in practice those laws are not enforced. Consider this example from Nigeria. Since the 1950s, Ogoniland - the homeland of the ethnic minority Ogoni people of the Niger Deltahas been targetted for crude oil extraction by a number of oil corporations, including the Shell Oil Company. As a result, it has suffered extreme environmental damage as a result of decades of indiscriminate petroleum waste dumping. Many have blamed the Shell Oil Company for the country's ills: the environmental degradation of the land and waters of Ogoniland, the corruption, and the oppression. Shell and other petroleum corporations are also blamed for the inaction of the Nigerian state, which was reluctant to enforce environmental regulations on the foreign petroleum corporations operating in the area. Those corporations came to be seen as unaccountable to the people. In this case, the Shell Oil Company had commitments to protect the environment that were in principle legally recognised, but in practice not enforced, due to the inaction of successive governments.

Implicit commitments can also be enforceable. Suppose the legal system in the Nigerian State were in better health. Then, Shell's implicit commitment to limit environmental damage would be enforceable.

There are also legal devices to enforce implicit commitments other than just the commitment to follow the general law. Estoppel is one such device in common law

\footnotetext{
${ }^{24}$ The ACC case is found in Thompson (2005: 305). It may have been that ACC had an existing implicit commitment to better ensure the safety of workers producing Kepone, because it was their chemical, and ACC was aware of the risks involved in manufacture. Thus, it had some responsibility for ensuring its production did not cause harm. ACC's recognition of this implicit commitment was the impetus for making the commitment explicit. Had it not made it explicit, though, it would remain as implicit and unenforceable.

${ }^{25}$ Thanks to an anonymous reviewer who recommended bringing out this point more clearly. An illustrative case to further help draw the contrast between legal and moral obligation is the following. In the late 1990s, Volkswagen faced mounting class-action cases from Holocaust survivors, who were used as slave labour during World War II. But, it denied any legal responsibility for compensating those survivors, claiming it was forced to use slave labour by Hitler's Government. However, VW then set up a \$12 million fund for these survivors: 'Hoping to put the conflict and bad publicity behind them, Volkswagen executives abruptly reversed their policy and acknowledged a "moral responsibility" to survivors of slave work.' VW still did not recognise a legal duty to compensate, but did recognise a moral duty to do so (see Andrews 1998, LeBor 1998).
} 
legal systems. ${ }^{26}$ Suppose, for example, the property management corporation of an office complex is responsible for the belief of a tenant company that forthcoming rent payments will be discounted, due to planned building works. Suppose this is not stipulated in contracts or even in an explicit promise. If the tenant company proceeds to rely on the planned costs from reduced rent, by spending elsewhere, and can demonstrate that there were legitimate grounds for forming this belief (from the management corporation's actions), then the property management corporation can be estopped from taking the tenant company to court for non-payment of full rent. The implicit commitment the management corporation made can be legally enforced. ${ }^{27}$

These different categories of commitment are relevant to corporate trustworthiness in different ways. It might be that fulfilment of an enforceable commitment reveals little about a corporation's trustworthiness, because the corporation could not have done otherwise. On the other hand, fulfilling an unenforceable implicit commitment will indicate a broader trustworthy character: the corporation takes seriously the commitments it has, even if not explicitly stated, and even if those commitments were not going to be enforced.

One final point: whilst we have highlighted the distinction between legally enforceable and unenforceable commitments, we might also make the distinction between scenarios where commitments can be enforced without recourse to the law, and when not. In particular, a corporation and its leadership can be subject to social threats such as protest, campaigns, strikes, reputational degradation, pressure from institutional investors (such as BlackRock and Vanguard; corporations that are increasingly invested in social issues), ${ }^{28}$ and social ostracism, which may make a non-legal, perhaps even implicit commitment, de facto enforceable. By contrast, if corporations or others can prevent such social pressure, perhaps by paying for effective lobbying and public relations campaigns, or counteracting labour mobilisation, it can make such commitments de facto unenforceable. ${ }^{29}$

\subsection{Fulfilment and breach}

Depending on the type of commitment, fulfilment might be a specific event: for example, the construction corporation pays the contractor for the work done. It might

\footnotetext{
${ }^{26}$ On estoppel, see Farber \& Matheson (1985).

${ }^{27}$ This type of case is discussed in more detail in Section 2.4.

${ }^{28}$ Thanks to an anonymous reviewer for helpfully drawing our attention to this form of de facto enforcement.

${ }^{29}$ For example, between 2011 and 2014, US corporation Target released a series of anti-union videos: an example of corporate campaigns to undermine unionisation efforts, which appear to have been successful in the US (Wang 2014).
} 
be to uphold an ongoing process: for example, preventing user data from being leaked. If the corporation fails to carry out the specific action that it has committed to, or fails in avoiding what it has promised not to do, it breaches commitment. Here different kinds of breach are outlined. Breaches can occur from intentional decisions to pursue self-interest, or through inconsistency in the activity of the corporation's agents, ${ }^{30}$ or through having conflicting commitments.

Breaches can be the result of intentional decisions by the corporation's decision-making body. The cost (including social/reputational) of a breach might be deemed 'worth' it. For example, when Ford Motors introduced the Pinto to compete with the compact cars of rival German and Japanese companies, the president and board were fully aware that the model had a faulty fuel tank that often ruptured during rear-end impact. With the help of engineers, they did a cost-benefit analysis, and decided that the benefit from selling the car to cost-conscious buyers outweighed the cost of foreseen legal action. ${ }^{31}$

Another type of breach occurs due to actions or inactions of the corporation's agents. A defective internal structure can result in the corporation doing things that run counter to its commitments, whether or not the management explicitly demand this. This can be due to incentive structures being in place that make it rational for agents to behave in ways that lead to breaches. ${ }^{32}$ For example, in the LIBOR scandal, several banks breached their commitments to report accurate interbank loan interest rates. This did not arise from an intentional management decision. It was due to individual rate-setters colluding with traders, who stood to benefit from dishonest rates being reported, in return for favours. ${ }^{33}$ However, whilst no intentional management decision was taken to breach such commitments, management did intentionally design the system of internal checks that made such dishonesty possible. The structure of that system enabled, and arguably encouraged, the corporation's own agents to act in dishonest ways that would also profit the bank. ${ }^{34}$

\footnotetext{
30 'Agents' here meaning employees or individual departments.

${ }^{31}$ On this basis, Ford launched the Pinto onto the market. However, it was wrong to judge that it was 'worth it' as the decision cost the company forty court cases and hundreds of millions paid in fines (Birsch \& Fielder 1994). An anonymous reviewer helpfully points out that such a decision may be deemed rational on some theories of corporate law (those in the 'rational choice' tradition).

${ }^{32}$ These are often due to 'failures of ethical oversight' (Thompson 2005: 247), which can occur prospectively when able to be anticipated, and retrospectively when failed to be corrected (Thompson 2005: 251-3).

${ }^{33}$ Binham (2013).

${ }^{34}$ Alternatively, breaches can be due to simple bad institutional design, with inner over-compartmentalisation or siloing leading to miscommunications, poor delivery, and so to outward unreliability (see Malhotra 2014).
} 
Not all breaches of a commitment undermine the trustworthiness of corporations: if the corporation either has a justification or a (fully exculpating) excuse. ${ }^{35}$ For example, it is generally accepted that self-defence or defence of another, can be a justification for breaking almost any other commitment. By contrast, where one's capacity to make a choice has been compromised by forces beyond one's responsibility (for example, one is drugged), then one may be excused of guilt in breaching a commitment. Natural disasters, new government regulation, wars, and so on, might foreseeably ground justifications for corporations to break commitments. ${ }^{36}$ External manipulation, or being the victim of false information, or espionage, could reasonably ground excuses for corporations breaking commitments. ${ }^{37}$

A corporation may sometimes face a conflict of commitments: for example, between stakeholders, or between stakeholders and shareholders. As a matter of reality, it will need to break one commitment to meet another. However, such a conflict will rarely amount to an excuse or justification for so breaking a genuine commitment. A constitutive part of acquiring and keeping any commitment is to ensure that one can and should keep the commitment. In other words, a trustworthy agent not merely fulfils her commitments, but always makes sure that her commitments are consistent in order to so. An aggrieved party may both admit that a commitment to another party takes precedence, but also hold a corporation accountable for allowing the conflict in the first place. This still leaves, however, the difficult moral question of which commitment should be prioritised, and why, when they do conflict. ${ }^{38}$

\footnotetext{
${ }^{35}$ Following D'Arcy (1963), we can say that an act (such as breaking a commitment) is justified when the agent is morally responsible for it, but it is, in the circumstances, not morally wrong. Breaking a commitment with justification does not corrode your trustworthiness at all. If the act (again, like breaking a commitment) is excused, it is morally wrong, but the agent is not morally responsible for it, and hence not guilty, because some special circumstances obtain. An excuse may qualify the corrosion. In other words, justifications corrode the moral obligations to fulfil commitments; excuses diminish moral responsibility for fulfilling commitments.

${ }^{36}$ For example, national security concerns might foreseeably ground justifications for Google to break commitments to its users' privacy.

${ }^{37}$ Consider Facebook. It made commitments to protect the privacy of its users. But in March 2014, it said that all of its 2.2 billion users should assume malicious third-party scrapers had compromised their public profile information. CEO Mark Zuckerberg's excuse for the breaking of the commitment to user privacy was that 'malicious actors' manipulated 'Search' tools on its platform to discover user identities and collect the information of 2 billion users around the world (Kumar 2018). A further question arises in whether Facebook should have foreseen and taken measures to prevent such actions, but this would require more examination of the breach, and whether this could have been reasonably anticipated and prevented.

${ }^{38}$ We will not venture into this topic (see, for example, Owens (2016) on how it is possible to gain conflicting promises). However, as a general principle, it is unlikely that a corporation has the moral right to prioritise commitments to its shareholders over other agents, if those shareholders are themselves ultimately responsible for the ongoing management of the corporation in the first place. However, this may
} 


\subsection{Reliance}

To rely upon someone is distinct from merely predicting that they will act in a certain way. It is distinct in two related key ways.

First, reliance entails vulnerability, where mere prediction does not. This is to say that we must have something at stake from another's action: that is, be in a position of potential loss or harm. ${ }^{39}$ As such, when we rely on a corporation to fulfil a commitment, we must be vulnerable or at risk from harm arising from a breach of its commitment. ${ }^{40}$

Secondly, when one acts on a prediction, one may adopt a 'calculative stance', by responding to the mere probability of that prediction being (becoming) true. Thus, one might undertake extensive contingency plans, or hedging ${ }^{41}$ to mitigate the

lead to counterintuitive results. In 2016, BlackRock (the world's largest asset manager) had made commitments to its shareholders (in the form of corporate statements, investment warnings, and internal policies) that it would use its influence to bring about greater environmentally conscious policies in client companies, with the aim of combatting risks posed by climate change. But, it also had commitments to the client corporations it invested in. The director of one of BlackRock's shareholders (Timothy Smith of Walden Asset Management) publicly criticised BlackRock's record of voting 'no' on the passing of environmental measures at the annual general meetings of its client companies, which it did at the behest of its client corporations' directors. This is a case where the commitments BlackRock had to its clients were in tension with the commitments it had made to its own shareholders. Yet, it seems plausible that, because the commitments BlackRock had to shareholders were 'socially conscious', those commitments should have held priority over those it had to the client companies' boards (see Mooney (2016) and Smith (2017) for this example). It is worth noting that since 2016 BlackRock has increasingly made commitments to tackling climate risks and supporting sustainable practices through its investment strategy (see BlackRock's Mission Statement on Sustainability 2018, Chasan 2017).

${ }^{39} \mathrm{It}$ is also for this reason that trust involves supposing that another is competent and willing (see Jones 1996). Without competence and willingness, a trustee would fail to perform what is trusted of them.

${ }^{40}$ Philosophers typically argue that trust involves reliance (Baier 1986, Hawley 2014, Helm 2014, Hieronymi 2008, Holton 1994, Jones 1996, Pettit 1995, Walker 2006). Sociologists Lewis and Weigert (1985: 971) say trust involves 'the undertaking of a risky course of action ...'. Robinson (1996: 576) characterises trust as 'about the likelihood that another's future actions will be beneficial, favourable, or, at least, not detrimental to one's interests'. A widely cited definition in organisational studies from Rousseau et al. (1998) (arrived at via an interdisciplinary literature review) includes risk, claiming that trust involves 'the intention to accept vulnerability based upon positive expectations of the intentions or behavior of another' (1998: 395). Sometimes, though, risk and vulnerability are tied to calculative, predictive expectations. Researchers in the rational choice tradition, such as Dasgupta (1988: 51) and Gambetta (1988: 217), claim that trust is a probabilistic, calculative expectation of the actions of another, that have a bearing on one's own choice of action, before we can monitor those actions. Coleman (1990: 92) ties the extent of trust to the amount of capital risked, in a transaction. But see below on why such views are mistaken in tying risk to the calculation itself.

${ }^{41}$ D'Cruz (2015: 472) puts hedging in terms of the 'strategy of insuring oneself against a loss', and that 'at its core, hedging is a defensive posture in the face of uncertainty, a method of mitigating the severity of feared negative outcomes by expending resources to protect oneself in the event that those obtain.' Hedging is common in finance, with derivatives, swaps, futures, and options being used for hedging. It is 
possibility of non-performance. However, when one is relying upon another, one acts as if performance were certain. ${ }^{42}$ Reliance requires not adopting contingencies against risk. If you do contingency plan, you are no longer relying. ${ }^{43}$ Performance becomes an assumption in one's planning. ${ }^{44}$ Thus, reliance on another's acting involves risking interests, goals, resources, etc. on their action. ${ }^{45}$

One may have no choice but to rely. For example, consider the position of Justice Obini, a cocoa farmer in Ghana in West Africa. ${ }^{46}$ Obini's cocoa beans are highly sought after. However, like the 800,000 other families in Ghana, he and his family are directly dependent, at least in part, on a living by cocoa farming. Obini struggles to take care of his farm and his family of ten. He plans his life and the education of his children, on the basis that he will receive a certain price for his beans. While there are many actors in the cocoa supply chain, cocoa farmers in West Africa are the most vulnerable and least empowered of any of these actors. The farmers say that they are powerless with respect to the price they receive for beans, which is strongly influenced by Hershey's, Nestlé, and consumer power in wealthier countries. As Samuel Toribi (another farmer) puts it, 'The manufacturers, the consumers - they control the price of our cocoa. The economy decides. So, we depend on them. ${ }^{47}$ Justice Obini and

also a common term in discussions of trust in International Relations. The absence of hedging in interactions between states is used as a key indicator of the presence of trust, where trust is opposed to calculative, strategising behaviour. The presence of hedging amounts to a relationship being contaminated with distrust, and so not genuinely trusting. Ruzicka and Keating (2015: 17) put it as follows: 'To have a trusting relationship leads states not to hedge against the potentially negative consequences of other's actions because such actions are cognitively considered to be zero within a trusting relationship.' There is an implied connection between one nation recognising the possibility of 'defection' by another, and the adoption of hedges - that is, the making of contingency plans. So, one nation truly trusting another, leaves the former open and vulnerable. Had it hedged, it must not have been trusting. Coleman's (1990: 92) examples of trust as the amount of capital risked also involve no contract, where that could be seen as a form of hedging.

${ }^{42}$ Williamson $(1993: 463,484)$ agrees that 'calculative trust' is a 'contradiction in terms'.

${ }^{43}$ As Holton puts it, in the example of a drama class 'trust circle'; 'when I let myself fall, and do not put out my hand to save myself, I am relying on you to catch me' (1994: 69).

${ }^{44}$ Alonso (2009, 2014), Hawley (2014: 4), and Holton (1994: 65).

${ }^{45}$ Baier (1986: 234-5), Black (2004), and Smith (2010); see also Railton (2014). Some trust researchers make explicit the connection between vulnerability and reliance. For instance, Hill and O'Hara (2006: 1724) suggest that, 'Trust experts all seem to agree that trust is a state of mind that enables its possessor to be willing to make herself vulnerable to another - that is, to rely on another despite a positive risk that the other will act in a way that can harm the truster' (see also McCraw 2015: 4-5). Hawley (2014: 8) suggests that 'the notions of accepted vulnerability plus foregoing the attempt to reduce such vulnerability capture roughly the notion of reliance.'

${ }^{46}$ Justice Obini is quoted in NBC News (2014).

${ }^{47}$ Samuel Toribi also quoted in NBC News (2014). 
Samuel Toribi plan for important goals in their lives on the basis that large corporations like Hershey's and Nestlé will keep prices at a certain level. They are at risk of not attaining these goals if prices drop below that level.

\subsection{A robust disposition}

A trustworthy corporation is a reliable corporation: that is, one that is worthy of being relied upon to fulfil its commitments. Being worthy of reliance is a matter of having a robust disposition to do what others rely on you doing. In the context of corporations this is a matter of how the corporation is structured, resourced, incentivised, and motivated. Sources of such a robust disposition can be both 'internal' and 'external'.

A corporation may undertake various measures with respect to itself to ensure reliability. Let us call these measures 'internal', whether motivated by other 'external' measures or not. Internal measures may be established routines or processes. ${ }^{48}$ Creating these can be costly. They may include creating a particular type of corporate culture; adopting certain values $;^{49}$ and building governance structures that are more effective in ensuring that those values are adhered to. ${ }^{50}$ They may involve proactive training and screening, and reactive internal disciplinary regimes, or reward schemes.

\footnotetext{
${ }^{48}$ Consider an energy supplier who is relied upon by a wide range of different customers; including private businesses, public sector institutions, individuals, families, and old people. To reliably provide energy to each will require investing in reliable physical and human infrastructure, training of engineers and representatives. A customer service advisor must be trained so they can fulfil the reliance of various customers. That will be a function of the corporation having invested in good training and customer service processes, that are then borne out in the experience of the customer. Part of the proactive features of the corporation are such established ongoing routines. Related to this: Child and Möllering (2003) argue, using empirical data from corporations based in Hong Kong with offices in China, that building interorganisational trustworthiness requires the establishment of stable, routine policies and procedures. On routine-based trust, see also Zaheer (1998) and Zucker et al. (1986). See also footnote 122, on budget airline reliability.

${ }^{49}$ See, for example, Citigroup's pledge to customers (footnote 17). On the importance of corporate values, see Mayer (2013: 193-4).

${ }^{50}$ Mayer (2013: 191-3) outlines how the three oldest UK family-owned corporations value consistency and quality, despite not earning as much as competitors. 'What marks out these and other oldest surviving independent corporations is the emphasis that they place on product quality and reliability' (Mayer 2013: 191). The 2013 KPMG Integrity Survey summarises causes of corporate misconduct reported by employees at various different levels and across different industries. The survey highlights the importance of internal values, codes of conduct, and how those result in different incentive structures. It states that, 'the most commonly-cited driver of [corporate] misconduct continued to be attributed to pressure to do "whatever it takes" to meet business goals.' It also highlights the importance of whether ethics programmes are in place, whether codes of conduct are taken seriously, and 'management's commitment to integrity' (KPMG 2013). These are clear examples of how internal features of the corporation affect corporate trustworthiness.
} 
They may involve stress tests, and risk analysis, seeking the weakest points in the corporation's design, to ensure fulfilment of commitments. ${ }^{51}$ Furthermore, they may involve internal auditing, feedback, and review measures that respond to risks or past breaches, reforming, correcting, and nudging to improve reliability. ${ }^{52}$ Finally, as corporations become larger, there will be increasing compartmentalising of actions, and delegation of discretion within corporations. This presents a risk to the corporation, as a whole, of acquiring inconsistent commitments. ${ }^{53}$ To remedy this, corporations must invest in processes to enable crosstalk between different departments, at key stages; providing clarity of overall purpose in order to align the exercise of discretion; and, in some cases, breaking up and selling off inconsistent activities. ${ }^{54}$

The most important point for this paper is that, regardless of which measures may be best to increase reliability, they may be very costly to the corporation. And, these measures may or may not result in compensating revenue and investment. It will depend upon how various markets, and regulators, value such reliability. ${ }^{55}$ In other words, what internal measures a corporation will take to improve its trustworthiness will in many cases be a consequence of what external measures are in place: for example, whether certain forms of regulation are valued and reliably enforced.

\footnotetext{
${ }^{51} \mathrm{BHP}$ (a mining corporation) invested in internal features to uphold commitments on the company charter to preventing employee fatalities; demonstrating reliability and so trustworthiness in respect of this commitment. An extensive infrastructure is in place, geared toward ensuring fatalities are prevented. Proactive feature: all employees must undergo extensive training surrounding safety; reactive feature: alerts about employees in danger in one location will direct human resources in other locations to help the employee in danger at any time. In contrast, consider the lack of robust internal measures in the automotive parts manufacturer Takata Corporation, resulting in its breaching commitments to safety standards. Takata employees in the USA reported concerns about the safety of airbags produced in its Japanese plants, but these were not followed up (Spector 2015). Takata could have ensured reliable compliance with commitments to safety by instituting a means of internal reporting to a trust board, to follow up on such reports.

${ }^{52}$ See Greenwood and Van Buren (2010: 429-30) on ways in which an organisation can be trustworthy: personal, systems, process, and institutional. By contrast, the Libor case reflects a lack of internal controls in the banks' own reporting procedures. More robust internal accountability procedures would have avoided the massive fines imposed on banks, and ensured that the banks' agents were working toward fulfilling legal commitments to accurately report Libor rates. Better ongoing accountability methods would be an example of an internal mechanism for increased reliability. Implementation of responsive features, such as procedures for whistleblowing, would also have decreased risk of breach.

${ }^{53}$ Malhotra (2014) argues trustworthiness of big corporations is undermined by actions being too compartmentalised within corporations, '... making it easy for organizational actors to ignore the externalities and broader consequences of their activities' (53). He suggests that corporations should devote resources to gaining an overview of how the actions of different departments lead to consequences beyond those departments.

${ }^{54}$ For example, in 2017, the Governor of the Bank of Japan reported that the services sector had undertaken corporate streamlining in order to avoid passing on labour costs to consumers (White 2017).

${ }^{55}$ See Section 3.
} 
A corporation can be made more reliable with respect to commitments by external measures, that will lead to more reliable internal measures. ${ }^{56}$ Such measures can be proactive, in the sense that they act to invigilate, recommend, and/or dictate the corporation's internal measures. For example, the state may set voluntary or compulsory safety standards, and undertake inspections to ensure compliance, or mandatory reporting and auditing. ${ }^{57}$ In terms of reform, one possible 'proactive' measure is that all parts of a corporation be mandated to create a 'Stakeholder Impact Report'. As Malhotra (2014: 77) puts it: 'The SIR would consider not just the direct effects of actions on all stakeholder groups, but also the effects that the organization and its employees have when acting in concert with other economic entities.' It would assess potential impacts, and likelihoods. Then companies could have teams within different parts to manage SIRs (77) and, individuals like a Chief Risk Officer (78) tasked with overseeing managing and acting on SIRs across teams. ${ }^{58}$

Alternatively, external measures can be reactive, incentivising internal measures ex ante by the threat of punishment or offer of reward ex post. Obviously, the law operates as an external reactive and punitive measure with respect to legally enforceable commitments. But, as mentioned above, protest, campaigns, strikes, reputational degradation, investor pressure, and social ostracism can also be effective external reactive measures. However, rewards can also be effective: for example, financial and social recognition (for example, from socially minded institutional investors like BlackRock) validating and valorising trustworthy behaviour.

External measures, proactive or reactive, are paradigmatically undertaken by the state. ${ }^{59}$ But, particularly with respect to legally unenforceable commitments, they can be instituted by other social actors: guilds, professional bodies, unions, consumer groups, invigilating NGOs, and so on. Corporations can also work together to resolve their own collective action problems with respect to reliability. For example, corporations within an industry could create inter-organisational stakeholder impact

\footnotetext{
${ }^{56}$ For example, it might use what behavioural economists call 'commitment devices'. On this, see Ariely \& Wertenbroch (2002), Brocas et al. (2004), and Gharad et al. (2010).

${ }^{57}$ Auditing is a proactive external measure that can improve corporate reliability, so long as the auditing profession itself is reliable (see Gustavson \& Rothstein 2013).

${ }^{58}$ Malhotra (2014: 79-80) also puts forward the suggestion of creating a governmental 'Stakeholder Impact and Vulnerability Board', whose job is reporting on 'business, economic and political activities of large and/or heavily interconnected firms' (80) on the impact of their actions, to stakeholders. This information could be made public, to enable stakeholders of different kinds to make better choices. An obvious question raised is how costly this would be to run, if the task of the board was to report on all corporations. And, if not all corporations, it would require some advance knowledge that there are types of risks associated with particular types of corporation. But then, the board would have limited efficacy. ${ }^{59}$ Often, failures of institutional trustworthiness are a product of excessive trust between malefactors and their overseers, either internally or externally (Thompson 2005: 252). Another way of framing this is the way personal loyalty can conflict with overall integrity (see Uggla 2013).
} 
assessment panels. The purpose of these would be to reduce the risk of unreliability that results not from a single corporation's actions, but the actions of multiple corporations in an industry. ${ }^{60}$ This was the case when the interdependence of multiple banks' activity lead to the LIBOR scandal and financial crisis. Corporations may also sign up to systems of accreditation and certification. It could be required that becoming, for example, an investment banker should require professional accreditation. Similarly, an agreement among companies to ensure that products and transactions meet standards, such as ISO 9000 (a family of standards that stipulate how a company should effectively meet stakeholder needs, while adhering to regulatory requirements), can be a way of improving reliability. ${ }^{61}$

Overall, relying on a corporation does not involve contingency planning; a reliable corporation saves on practical costs to the other agent. Reliable corporations will reliably perform, and other agents will not have to absorb the costs of unreliability; in incurring losses, or in implementing prior contingencies in case of failing. Different measures can be taken to increase corporate reliability. However, the question remains as to which parties, if any, ultimately ought to bear the cost of such measures, and this frames the fundamental concern of this paper.

\subsection{Rational grounds}

A trustworthy corporation is one that can be rationally relied upon to fulfil commitments. It is only rational to rely upon a corporation, however, where one has good reasons to believe that the corporation is robustly disposed to fulfil its commitments, over a range of possible different salient intervening circumstances. In other words, where one has good reason to believe the corporation is reliable.

Based on the previous section, an obvious source of good reasons to believe that a corporation is trustworthy will be recognition that there are systems in place to ensure reliability. So, we might presume that seeing a corporation meets certification standards, for example, will be a source of evidence for trustworthiness. But this may depend on the other agent: most customers do not look for certification standards as

\footnotetext{
${ }^{60}$ Malhotra (2014: 78): To prevent problems like the financial crisis this will 'need coordinated action from firms that are currently co-acting blindly.'

${ }^{61}$ Gustavson and Hallström (2013) note the paradox underpinning certification: that it builds trust in an industry by implementing a baseline level of mistrust. They also note that, in order to trust the certification system, one must hire accredited professionals to perform checks - 'metacertifiers' - though this then depends on trust in the accreditation system (101). Walgenbach (2001) argues that, in fact, ISO 9000 certification standards have not increased trust by customers, but are rather welcomed by companies as a means for reducing transaction costs between them.
} 
evidence of trustworthiness, but other corporations and contractors might. ${ }^{62}$ Furthermore, most transactors will not be in a position to see the internal proactive and reactive measures that ensure the corporation's reliability. ${ }^{63}$ The lines of reporting/ accountability and inner procedures that provide reliability will be hidden. The only evidence that transactors can typically have will simply be ongoing fulfilled reliance.

Without a history of interactions with the corporation, another agent will go by other sources for evidence of reliability. One of these may be the corporation's reputation. Reports from others (such as social media reviews) about the reliability of the corporation, in respect of its various commitments, will influence the beliefs of prospective transactors. Reputation can also be affected by perceptions of the sector that the corporation belongs to. For example, that the banking system is perceived as unreliable with respect to commitments, will lead to other agents being wary of individual banks. ${ }^{64}$ An individual bank, even if it has been reliable in the past, will therefore need to do more to be perceived as reliable, against a background of unreliability. ${ }^{65}$ If the bank in question was participating in activity that led to breaches of commitments, then that bank would have to do even more to improve its reputation. ${ }^{66}$

One way of doing this would be to explicitly avow commitments that were once implicit, that the corporation previously breached. For instance, when Richard Wagner of ACC avowed a commitment to the health and safety of workers in contractors, the act of making this explicit invited others to hold ACC morally accountable for failing to do so in future. Making commitments explicit expresses that the corporation takes fulfilment seriously. ${ }^{67}$

\footnotetext{
${ }^{62}$ See Walgenbach (2001).

${ }^{63}$ Increasing compartmentalising makes it more difficult for stakeholders to evaluate the trustworthiness of a corporation. This could lead to a situation of increasing stakeholder trust, despite more corporate untrustworthiness (Malhotra 2014: 53-4). There are situations where evidence of increased compartmentalisation without good crosstalk, leads to a perception of unreliability. Consider how the experience of being passed around different departments on a customer service line can diminish the perceived trustworthiness of the corporation.

${ }^{64}$ de Bruin (2015). 'Systemic' or generalised trust of an industry is further discussed in Section 5.4.

${ }^{65}$ In this way, the actions of other corporations in an industry could in principle lead to costs being imposed on individual corporations, which are themselves reliable, in having to do more to indicate trustworthiness.

${ }^{66} \mathrm{~A}$ recent relevant case can be found in the reputation of Australia's main banks, in particular AMP. The Australian Royal Commission in the Banking, Superannuation and Financial Services Industry has investigated misconduct in the banking sector, and four of the main banks (CBA, Westpac, NAB, ANZ) have lost just under 5 per cent share value. The performance of AMP at the hearings, having to answer for repeatedly misleading the ASIC (the corporate regulator), has resulted in its share value dropping more than 20 per cent. AMP will have to do even more to improve its reputation in light of the widespread misconduct in the sector, while also being one of the worst offenders. See Chau (2018) and Letts (2018). ${ }^{67}$ Explicit commitment is a way of making clear that you grant others the normative power to hold you accountable for failing to act in some way. For instance, Owens' (2006: 70-1) account of promissory
} 
Another way of demonstrating reliability can be to voluntarily allow others to make your commitments enforceable. For example, a construction corporation can make the commitment to pay a contractor on time, but also sign a contract to this effect. The construction corporation therefore must be reliable with respect to the commitment, because the law can require it to pay.

However, endorsing the use of external measures as evidence of reliability, and so trustworthiness, needs qualification. Using devices like contracts can in fact 'crowd out' trustworthiness. ${ }^{68}$ This is because it is then not clear whether the corporation itself is trustworthy, or just had its hand forced. Had the external measure not been in place, the corporation may have not fulfilled the commitment. Also, in the example of a construction corporation using a contract to stipulate terms of payment to a contractor, this is just as much to enforce the work from the contractor as it is to enforce payment from the corporation. The contract can also crowd out the scope for trustworthiness of the other agent.

This said, the use of a contract may be a way of gesturing that the corporation takes a commitment seriously. If repeat transactions indicate that the source of fulfilment of the contract is more a result of the internal reliability of the corporation, rather than the threat of enforcement, this could arguably indicate trustworthiness to the other agent. It indicates that the corporation is built on the basis of values that give weight to reliability in meeting its various commitments.

\section{WHAT IS THE VALUE OF CORPORATE TRUSTWORTHINESS?}

'Without fidelity and trust, there can be no human society. ${ }^{69}$

'Whatever matters to human beings, trust is the atmosphere in which it thrives.' 70

'Men live upon trust.'?1

'A complete absence of trust would prevent [one] from even getting up in the morning.' 72

obligation explains that, in making a promise (understood here as equivalent to a commitment), one grants others the authority to hold you to account for breaches. We have this normative power as a way of showing respect for one another: "promises are often welcomed because the promisee wants a display of respect for their capacity to take decisions in a matter of importance to them' (72).

${ }^{68}$ This is a well-supported conclusion from empirical literature on the effect of contracts in interpersonal trust games. See, for example, Bohnet et al. (2001), Malhotra \& Murnighan (2002), and Mulder et al. (2006). See also Winter (2011) on how performance-based pay for executives can result in a similar crowding-out of 'ethicality'. Related to a point made above in footnote 50; performance-based pay can be an incentive that leads to executives doing 'whatever it takes to increase their earnings, including actions that are at the expense of commitments.'

${ }^{69}$ Reid (1846: 666).

${ }^{70}$ Bok (1978: 31).

${ }^{71}$ Locke, letter to Tom, 20 October 1659 (in de Beer 2010: 123).

${ }^{72}$ Luhmann (1979: 5). 
Within philosophy, sociology, political science, and economics there is no shortage of paeans to the general value of well-founded trust. ${ }^{73}$ However, most discussion, at least with respect to corporations, has simply focused upon one type of value: increasing efficiency. In this section, we shall distinguish this type of value from four others relevant to our discussion: decreasing the probability of interference; showing respect; validating reciprocity; and safeguarding against subordination. ${ }^{74}$ We shall also reject one putative value: decreasing domination.

\subsection{Increasing efficiency}

Achieving much that is valuable in society requires agents, including corporations, to rely upon one another to meet commitments: whether in contract, in collaboration, or simply to obey the general law. Without good grounds to so rely, agents are deterred from engaging in such potentially valuable ways, or are motivated to expend further resources making themselves less vulnerable to the risk of non-compliance. In other words, agents are less likely to engage in valuable collective and coordinated action, and/or the transaction costs of such action become higher. Ceteris paribus, without well-founded trust between parties, interactions are less efficient.

Thus, the first, and perhaps most prominent value of corporate trustworthiness is that it provides the basis for such well-grounded trust in corporations, which in turn will be conducive to greater collective and coordinated action with other agents, with fewer transaction costs. ${ }^{75}$

Numerous statements from regulators reflect how important corporate trustworthiness is for sustaining efficiency in financial markets. ${ }^{76}$ For example, The Wallis Report, which laid the groundwork for Australia's 'twin peaks' regulatory model, states that, '[f]inancial markets cannot work well unless participants act with integrity, to ensure mutual trust, and unless there is adequate disclosure to facilitate informed judgments. ${ }^{77}$ The Walker Review suggests that trust between major shareholders and the company create financial resilience and stability. It states that, 'trust

\footnotetext{
${ }^{73}$ Such 'utilitarian' reasons to favour trustworthiness (that is, because corporations being trustworthy best serves the interests of society) are also further discussed in Section 4. The utilitarian case cannot do the work of grounding a moral right to corporate trustworthiness.

${ }^{74}$ There are at least two other values that are not included: perfectionist - the value of being trustworthy as a virtue, essential in particular to integrity — and non-market - that is, in being constitutive of non-market values like love, friendship, family, and so on.

${ }^{75}$ Trust as a 'glue' or 'lubricant': Arrow (1974: 23) and Torbisco Casals (2015: 462).

${ }^{76}$ Thanks to an anonymous reviewer for emphasising this point and helpfully offering references to this literature. In addition to those quoted below, see Shipton (2018).

${ }^{77}$ Hanratty (1997; §7).
} 
and understanding [between major investors and the company] ... should stand the company in good stead in a time of stress. ${ }^{.78}$

At the level of basic one-on-one interactions, the importance of well-founded trust lies in how it increases efficiency by enabling reciprocity. Trust fulfilled in one interaction is liable to beget reciprocal behaviour in the next interaction: amplifying the instrumental value of any particular instance of trust. ${ }^{79}$ These dynamics apply in one-on-one relationships over time, in groups that have good grounds to trust one another, and in society in general. ${ }^{80}$ Most relevantly for this paper, it has been established in relations between corporations and other agents, and amongst corporations themselves. Such 'social capital', as Fukuyama has argued, is a key element of overall economic success. ${ }^{81}$

\subsection{Decreasing risk}

Whilst corporate trustworthiness can be instrumentally valuable by increasing the efficiency of collective and coordinated action, it is also valuable to the truster in any individual interaction. This is because it entails a decrease in risk.

As the old saying goes, 'a bird in the hand is worth two in the bush'. However, in general, one bird in the hand is also worth more than a commitment to be given one bird later on.$^{82}$ The reason is that any commitment involves the risk of non-compliance; and as that risk of non-compliance increases, so the value of the commitment decreases. This is, of course, reflected in market activity. Holding everything else constant, actors will value more, and be willing to pay more to receive commitments that are more likely to be kept, than not. ${ }^{83}$

\footnotetext{
${ }^{78}$ Walker (2009; §5.26). See also $\$ 5.31$ and Annexure 4: 'Transactional leadership fulfils contractual obligations which creates trust and establishes stable relationships with mutual benefits for leader and follower.'

${ }^{79}$ Trust leads to reciprocity: citizens obey the law, because they expect others to do so too (Lenard 2012). This is to highlight the instrumental value of reciprocity, however, as distinct from the normative value. (See Sections 3.4 and 5.5.)

${ }^{80}$ 'In large and anonymous political societies, general trust is often regarded as essential to secure general law abidance, to reduce the cost of large scale coordination, and to increase the opportunities for fruitful cooperation' (Allard-Tremblay 2015: 377, citing Sztompka 1998: 21-2; cf. also Offe's model (2000: 42-3)). ${ }^{81}$ Fukuyama (1995) and Rothstein (cited in Klitgaard 2015: 24): Corruption undercuts trust. 'Since social trust is an important intrinsic value (personal happiness, optimism about the future) and also has a political value (support for fair institutions, minority rights, tolerance, etc.) and an economic value (its positive relation to individual earnings and aggregate economic growth), it may be that dysfunctional government institutions are the worst social ill of all' (Rothstein, 2011: 162).

${ }^{82}$ This point is not universal. Sometimes the risk, and the fulfilment of the commitment are intrinsically valuable: creating bonds of loyalty, gift giving, etc.

${ }^{83}$ See Section 4.
} 
Once again holding everything else constant, therefore, trustworthiness increases the value of any particular commitment. A more trustworthy actor is less likely to renege than an untrustworthy actor. This forms the basis of the judgement that they can be relied upon to meet the relevant commitment.

This type of value of trustworthiness of course in part explains the behaviour which explains increases in market efficiency. Where there is less risk that a possible commitment will be broken, there is more incentive to so commit, and less incentive to invest in defences. However, it is important to recognise its independent value. There is simply a windfall gain, for example, for an actor who is either, by choice or otherwise, party to a corporation's commitment, and that corporation becomes more trustworthy during the course of the relationship. For instance, demand for tickets from a monopoly transport provider may be quite inelastic with respect to the reliability of the trains running on time. However, the value of the ticket to the consumers would increase markedly if the trains could be relied upon to run on time.

\subsection{Showing respect}

As discussed above, to make or acquire a commitment to another agent to do something is not simply to predict that one will do that thing, nor even merely to have good reason to do that thing (self-interested or otherwise). It is both to owe a duty of performing that thing to that other agent, a duty which overrides other competing reasons; and it is for that other agent to have a right to demand such performance, regardless of our other reasons, and hold us accountable if we fail to do so.

When any agent, including a corporation, treats a commitment as having this status - not merely when fulfilling it, but also in its consideration, plans, and preparations before doing so-it manifests an important kind of respect for the other agent. It recognises that the other agent is the type of being to whom things can be owed; that can rightfully demand that others act in certain ways; and can hold others accountable. It recognises this aspect of their agential status. It also recognises its own relative agential status: that is, it is not some higher being, or authority that can, at will, simply disregard, or overrule the rights of the other agent: like a king, feudal lord, or master with respect to her slave.

Corporate trustworthiness, therefore, as a disposition to reliably fulfil one's commitments to others, is valuable because it can be constitutive of such respect, if it is motivated, at least in part, by the duty to fulfil the commitment. By contrast, untrustworthiness as a disposition to not reliably fulfil one's commitments to others is a wrong because it manifests disrespect. ${ }^{84}$ It demonstrates an indifference to the other

\footnotetext{
${ }^{84}$ Or: being neither trustworthy nor untrustworthy.
} 
agent's agential status, and acting in a way consistent with having a higher status: as if there were one set of rules for oneself, and one set of rules for another. ${ }^{85}$

In this way, the trustworthiness of a corporation is valuable in this sense of showing respect, if it is motivated, at least in part, by the duty to fulfil its commitment to others. Such reasoning need not be front of mind in any decision by the board, executive, or surrogates, but it should at least show up if put to the test, hypothetical or otherwise, of asking if and why certain commitments must be kept in the midst of countervailing reasons such as self-interest. Respect is shown when the answer is something like 'we must do it because we made a commitment', 'because we owe it to the other party', 'because doing otherwise would just be wrong', and so on.

This point finds support in an influential report from the FRC (Financial Reporting Council), on Corporate Culture and the Role of Boards. This report emphasises the value of respect, which is enabled by well-founded and fulfilled trust. Sir Winfried Bischoff writes: 'I also ask investors and other stakeholders to engage constructively to build respect and trust, and work with companies to achieve long-term value. ${ }^{86}$

However, as we have been at pains to stress above, a corporation can be trustworthy regardless of its motivation, so long as it is disposed to reliably fulfil its commitments. ${ }^{87}$ As such, it may do so in a disrespectful manner, purely from self-interest, or for the sake of reputation, or even paternalistic, ideological reasons. Is such a situation valueless in terms of respect?

No. At least, in situations where the state (and/or other actors) within society have designed the corporation's incentive structure in this way (that is, so that the corporation does fulfil these commitments even if it is not properly motivated to do so), and they have designed the incentives this way because they acknowledge and are seeking to enforce the duty that the corporation owes, then the state and/or other actors manifest respect for the agent. In other words, the deployment of reactive or proactive, external or internal measures by the state that aim to establish the trustworthiness of a corporation, in pursuit of protecting the rightful claims of the other agents it interacts with, manifests respect for those agents, even if the corporation itself does not.

\subsection{Validating reciprocity}

Reciprocity involves responding to another in kind, in part because they have so acted with respect to you. For example, I might scratch your back, in part because you have

\footnotetext{
${ }^{85}$ Or at least where one is willing to demand that other live up to their commitments to you.

${ }^{86} \mathrm{FRC}$ (2016a: 3). Appealing to stakeholders to be involved too, stresses a point made above (footnote 8): that the burden to improve trust may not wholly lie on the side of the corporation itself.

${ }^{87}$ This is in accordance with Hawley's view (2014: 16).
} 
scratched mine. I might also trust you, in part because you trusted me. This is a fourth way in which trustworthiness can be valuable: if, by being trustworthy, I give you good grounds to trust me, and I fulfil your trust, then you have a reason to be trustworthy with respect to me, and fulfil my trust, and so on, in a virtuous cycle. In the language of 'respect', if you respect me, then I have an additional reason to respect you. Trustworthiness, therefore, is valuable in creating such grounds for virtuous cycles of trust and respect. The world of corporate governance is not blind to this point. The UK Corporate Governance Code (2016) remarks, for example: 'But certainly there is also scope for an increase in trust which could generate a virtuous upward spiral in attitudes to the Code and in its constructive use. ${ }^{98}$

However, trustworthiness is also valuable in preventing vicious cycles of distrust and disrespect. As Hobbes argues in the Leviathan, if I have good grounds to believe that you are not going to fulfil your commitment to me, then I have a prima facie justification to withhold performance of any commensurate commitment to you ${ }^{89} \mathrm{It}$ is an act of self-defence against being taken advantage of. Of course, if such distrust is common (as it would be in a Hobbesian state of nature), then almost any commitment is likely to corrode. As Seamus Heaney notes, terror is 'destructive of the trust upon which new possibilities would have to be based' ${ }^{90}$ Such a situation is instrumentally a disaster (inhibiting effective collective and coordinating action). However, it also excludes us fulfilling any commitments to realise justice with respect to one another. Our very moral fabric is liable to corrode. This is the reasoning that is at play when various actors refuse to play 'their part' with respect to ameliorating some injustice, because they do not trust others to play theirs. In particular, and as discussed below, where corporations cannot be trusted by citizens to pay taxes, address manifest injustices, or guarantee public goods, one negative effect is that such citizens, with some justification, may start to do the same. ${ }^{91}$

\subsection{Decreasing domination and increasing republican liberty?}

Some philosophers argue that there is a further specific harm in merely being vulnerable to another agent's power (and which cannot be explained in terms of the harms of commitment-breaking set out above: for example, showing disrespect). This harm is 'domination'. These 'republican' philosophers argue that domination is the essence of being 'unfree'. And true freedom is to live without domination. ${ }^{92}$

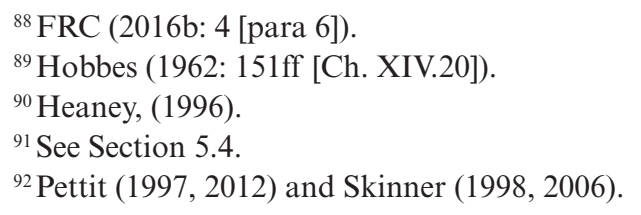


More specifically, the republicans hold that we are made less free not by being interfered with, or the risk of interference, but by the mere fact that another agent has the power to arbitrarily choose to interfere with us, or not. Such a power is 'arbitrary' in the relevant sense, when it is not controlled in any way by the person who could be interfered with (for example, when Ulysses compels his own sailors to tie him to the mast). Hence, to illustrate, in the paradigm case - the master-slave relationship - the slave is dominated by the master (and hence 'unfree'), not because the slave is interfered with (the slave may not be interfered with; the master may be lenient or uninterested), but because the master has the ever-present power to interfere (whether she happens to choose to do so or not) and the slave, of course, does not control the master..$^{93}$

Whilst initially very plausible and applicable to the substance of this paper, the very coherence of 'republican liberty' as a unique value, and 'domination' as a unique harm, not reducible to other values and harms described above, has been under great pressure in contemporary political philosophy. ${ }^{94}$ In order to be unique, the harm of domination has to exist, equally strongly, not merely when the risk of interference is high, but when it is virtually nil. In other words, one agent is made just as unfree by the mere possibility of arbitrary interference, and not made less unfree by the risk of interference increasing. This appears to be not only implausible and undesirable but, some have argued, impossible to achieve in a society where almost anyone could possibly interfere with anyone else, arbitrarily.

It follows, therefore, and most saliently with respect to this paper, that increasing trustworthiness (including corporate trustworthiness) would not decrease such domination, and increase 'republican liberty'. By definition, a trust relationship always leaves a residual possibility that the trustee may interfere with the truster. Furthermore, at least in the cases where trust is based on the internal virtues of the trustee rather than on external incentives, it is not clear why this does not remain a form of 'domination' according to the republican definition. After all, the master may be a virtuous and trustworthy master, committed to not interfere with her slave, but would this make the latter, less free? It is not apparent why it would. ${ }^{95}$

Given these difficulties, this paper excludes consideration of domination and republicanism: first, it is not clear that it properly explains the harm of vulnerability

\footnotetext{
${ }^{93}$ Historically, many have observed that the slave actually can control the master through the manipulation of the master's desires through flattery. See, for example, Rousseau's discussion of this phenomena in the Discourse on the Origin of Inequality (1755). We leave this complication aside here.

${ }^{94}$ Carter (2008), Gaus (2003), Kirby (2016) Kolodny (2014a, 2014b), Kramer (2008), Lang (2012), and Simpson, (2017).

${ }^{95}$ Pettit has an early essay claiming that trustworthiness does ameliorate domination (Pettit 1998); as well as a section in Pettit (1997: 246-7, 261-70). However, neither addresses these concerns, and perhaps not uncoincidentally the value of trustworthiness has entirely disappeared from his later remarks on the topic.
} 
(or, more specifically vulnerability to the 'arbitrary power to interfere'); and secondly, even if this were coherent, it is not clear how it could explain the ways in which trustworthiness could ameliorate such harms.

\subsection{Safeguarding dignity and the rightful distribution of power from subordination}

Arguably, driving the prima facie plausibility of the republican idea of 'domination', is a phenomenon we might instead call 'subordination' for the sake of distinction. By subordination, we shall mean where (a) one agent cannot rationally rely upon another to keep its commitment, and instead (b) she understands herself to be vulnerable to being coerced into performing an action she would not otherwise be obligated to perform, by the mere threat of the other agent breaching its commitment. ${ }^{96}$

For example, the majority of the Thai fisheries industry relies on a mostly international migrant workforce, poorly paid and working under highly authoritarian and unequal labour relations. ${ }^{97}$ The worst labour abuses occur on long-haul boats at sea for over a month where some 25 per cent of long-haul workers reported that they were not working willingly. The most frequently reported means of coercion was economic, through the withholding of wages, but a significant proportion ( 3 per cent overall, and 5 per cent of workers from Myanmar) reported violence and threat of violence. There have also been reports of witnessed executions of fellow workers as a way of enforcing compliance.

Such 'subordination' is distinct from 'domination' in three ways. First, it presupposes that the relevant agent under power understands herself to be in this position, and it affects her decision making. Secondly, it does not arise merely from the power to arbitrarily interfere, but from the power to force another to act in a way she would otherwise not be obligated to act, by the mere threat of the other agent breaching its commitment. In other words, it only arises when the powerful agent can use his ability to breach a commitment as a threat. Finally, the reasons that it is harmful are not because they inhibit freedom (at least as it is understood by republicans), but because it corrodes the dignity of the person under power, and undermines the rightful distribution of power within the society.

Let us look at these two harms in turn.

First, a person's dignity reflects her moral status as an agent amongst others. It is the basis from which she can choose and, most importantly for our purposes, be held

\footnotetext{
${ }^{96}$ Contrast Kolodny (2014b: 295-6).

${ }^{97}$ The information in this paragraph is based on Marschke and Vandergeest (2016). They also report that that this situation is enabled, in part, because employers can easily evade regulation given the informal nature of recruitment. An anonymous reviewer has helpfully pointed out that modern anti-slavery legislation (e.g., United Nations 2011) is intended to prevent this sort of practice.
} 
responsible for such choices. Without both the ability to choose, and be held responsible for those choices, one's agency, one's 'will', is compromised.

Mere disrespect by another does not degrade one's dignity. It is simply a failure to respond appropriately to it. It is a failure to recognise the choices and responsibilities of another, and what is owed to her as a consequence. By itself, it does not actually diminish the responsibility of another.

However, being placed, or even placing oneself in a position where one cannot be held responsible for one's choices, does degrade one's dignity. And, this is precisely what happens if one is in a position of subordination. In such a position, one loses control over one's will. Without such control, one cannot be held fully responsible for one's actions. This is demonstrated by the fact that, if a corporation were to coerce an agent to act in a certain way by threatening to break its commitments, then the relevant agent would be excused of responsibility for her subsequent action..$^{98}$

But notice, such responsibility is also compromised even if the corporation does not exercise that power to so threaten. So long as the corporation can be understood to be willing to use such a power if the agent were to act inconsistently with the corporation's preferences, then the agent's choice to do anything will always, at least in part, be because the corporation wanted her to do that thing, or at least not other alternatives. One is liable to live in subservience, adapting and compromising to the will of the corporation, compromising one's own individual responsibility, and thus dignity, in the process.

Secondly, the flipside of one individual losing power and control in such a situation is also to enlarge the corporation's. As such, this is an additional wrong arising from the situation of subordination. This is a wrong arising not from the harm to the relevant subordinated party, but the illegitimate benefit obtained by the corporation. By placing a corporation (or any other agent) in such a position (chosen or not), one effectively grants the corporation a power it should by rights not have. The existence of this dynamic, in a society, disturbs what can otherwise be assumed to be a just distribution of power; not just vis-à-vis the immediately subordinated power, but all other actors within the society. As such, no one (including a corporation) should be party to such a dynamic, whether this is as the subordinated party, or the subordinator.

\footnotetext{
${ }^{98}$ The chair of the Federation of Small Businesses (Mike Cherry) recently called for all FTSE 100 companies to acknowledge and tackle widespread 'supply chain bullying' - where large businesses use the disparity of power in business relationships to squeeze their suppliers by, for example, increasingly delaying payments. The collapse of Carillion in January 2018 highlighted how often the government-backed 'prompt-payment code', which committed groups to pay suppliers within a maximum of 60 days, was being ignored, with Carillion pushing payments back to 120 days (e.g., Gordon 2018). (The FSB has made ongoing calls for this problem to be tackled. (See also Gordon 2014.))
} 
Furthermore, at least in cases where the commitments are legally recognised and otherwise enforceable, the corporation arrogates to itself powers of which the state has otherwise sought to divest it. For example, the law may seek to exclude the power of a corporation to make employees work longer than certain hours. This may be primarily for the employees' benefit, but in many cases, it may be for safety reasons, or to ensure additional employees are hired, or to prevent an unfair competitive advantage, or for some other reason. Regardless of the reason, the law has legitimately sought to divest the corporation of this power, and may have taken a number of steps to enforce it. However, when an employee is placed, or even places herself, in a position where she can be coerced by the corporation into acting in this manner, she is effectively granting this power back to the corporation. In other words, it undermines the state's authority, by undermining its right to determine the distribution of power within a society.

Engagements between corporations and other agents that involve subordination, therefore, are unjust, and should not be permitted. But, how does trustworthiness ameliorate such a situation? How does trustworthiness turn a morally volatile situation of subordination into morally inert power difference?

As we have defined subordination, it arises only where another agent cannot rationally rely upon a corporation to keep its commitment, and thus, by definition, does not arise where the corporation is trustworthy with respect to such a commitment. But what justifies this definition? After all, an imbalance of power exists even when the other agent can rationally rely upon the corporation to keep its commitment, and there is always the risk that the corporation may defeat such expectations, or else it would not be a case of 'reliance' at all.

The reply is that such power is harmful — compromising dignity and illegitimately arrogated - only where the other agent cannot confidently act, with their head held high, as if there were no such risk. In such a scenario, the risk should not change her decision. It is should not affect the choices that she makes. And this is precisely to describe a state of reliance with respect to a commitment: that is, trust. ${ }^{99}$ As such, if a corporation is trustworthy, then it should make such relations of non-coercive power morally inert.

\section{A RIGHT TO CORPORATE TRUSTWORTHINESS?}

The trustworthiness of corporations, therefore, can be valuable on at least five independent bases: increasing efficiency, decreasing risk, showing respect, validating reciprocity, and safeguarding against subordination. However, just because

\footnotetext{
${ }^{99}$ See Section 2.3.
} 
trustworthiness is valuable - to others, or even itself — does not necessarily oblige a corporation to be trustworthy. After all, it has its own legitimate default reasons for action, even if they are not as narrowly construed as maximising shareholder value, and these may or may not align with being trustworthy, let alone the costs that must be incurred to achieve it.

So, when might a society, nevertheless, rightfully institute public policies to increase the trustworthiness of corporations, regardless of the corporation's default reasons for action? In this section, we distinguish between justifying such public policies, on the one hand, on utilitarian grounds; and on the other hand, as enforcing a right, held by other agents, to deal with such a trustworthy corporation.

\subsection{Utilitarian reasons to promote trustworthiness}

The first and most obvious reason the state and other actors may have to institute policies that increase the trustworthiness of corporations is simply utilitarian. It is the claim that policies designed to increase the trustworthiness of corporations - internal or external, reactive or proactive-would help maximise levels of well-founded trust, and hence overall social utility. Such utilitarian reasoning is not grounded upon any assumption that any other actor has a right to deal with a trustworthy corporation, or a corresponding duty on a corporation to be trustworthy. Instead, it is simply grounded on the assumption that it is the best thing for society overall.

Such utilitarian reasoning is evident in the legal and economic literature on regulation, ${ }^{100}$ and in the literature on social capital. ${ }^{101}$ However, such literature also indicates the limits of such reasoning. Whilst well-founded trust, by itself, may almost invariably increase overall social utility, the policies needed to increase trustworthiness may not. As already noted above, achieving trustworthiness can be costly for any corporation. It may need to establish layers of oversight; comply with laborious regulation; invest in training and culture; and so on. Furthermore, the social costs of such compliance are also liable to increase the barriers to entry within any market,

\footnotetext{
${ }^{100}$ See, for example, Mülbert \& Sajnovits (2017) and Stout (2011: 513). Also see Bratton \& Wachter (2010: 656-57, 716): this article refers to the post-global-financial-crisis goal of restoring investor trust as providing new policy rationales for stronger shareholder rights, and increased pressure for legislative change. ${ }^{101}$ Fukuyama (1995: 104) describes the usefulness of trust and trustworthiness in building up social capital, economic competence, and economic growth, when discussing northern and southern Italy. Despite being under the same national regulations, they developed quite differently, which Fukuyama attributes to social capital sustained by trust. See Narayan (1999) for further discussion of the usefulness of social capital.
} 
reducing overall competition. In some cases, the market may simply collapse if corporations cannot make a profit whilst complying with regulation. ${ }^{102}$

The overall social benefits, therefore, of policies that aim to ensure corporate trustworthiness will not always outweigh their social costs. Ultimately, it will always be an empirical question that should be determined on a market-by-market basis.

It is within this context, therefore, that the particular question of this paper becomes so important. This is because, if other agents have a moral right to deal with a trustworthy corporation, then that right may apply regardless of such a utilitarian cost-benefit analysis. This is to say, their right may act like a moral 'trump': justifying policy action by the state and/or other entities to promote trustworthiness even if they are otherwise socially 'inefficient' ${ }^{103}$ However, does such a right exist?

\subsection{Does mere vulnerability ground a general right to trustworthiness?}

As a starting point, one might be drawn to the view that, in fact, a very general right to trustworthiness might exist. On this view, if another agent is merely vulnerable with respect to the risk of a corporation failing to fulfil its commitment, then the other agent has a right that the corporation be trustworthy with respect to that commitment.

This paper has recounted elsewhere many such examples vis-à-vis consumers, suppliers, investors, employees, and even the state. In truth, almost all of us are somewhat vulnerable to corporations with respect to almost any commitment. This is because, despite, in most cases, nominally having the law and other mechanisms at our disposal to enforce compliance or demand compensation, for even legally enforceable explicit commitments, the transaction costs of engaging such mechanisms are not offset by the compensation on offer. In effect, it is impossible to receive full compensation.

If a corporation is not trustworthy, then any vulnerability in itself is a harm. First, by increasing the risk of breaching a commitment (relative to being trustworthy), the corporation will decrease the value of the commitment to the vulnerable agent. Secondly, by showing an indifference to fulfilling the commitment because it is owed to the vulnerable agent, it shows a certain disrespect to the vulnerable agent. And

\footnotetext{
${ }^{102} \mathrm{An}$ argument along these lines has historically been made concerning the US Sarbanes-Oxley Act of 2002 (SOX), which was intended to enforce greater accounting accuracy, in the wake of such high-profile scandals as Enron. The cost of compliance with the act is high on smaller firms, placing more of a barrier to entry into markets (see, e.g., Hanna 2014). Coates and Srinivasan (2014) give a multidisciplinary review of the effects of SOX, and estimated compliance cost on firms.

${ }^{103}$ There is also a further question of whether sometimes corporations should have a 'right' to operate free of such policies, even if it would create social inefficiency: for example, by libertarian reasoning.
} 
finally, in relevant cases, the vulnerable agent may pre-emptively renege on their own reciprocal commitments, or be placed in a position of subordination.

It is tempting, therefore, to directly infer from such harms of vulnerability some right to trustworthiness in order to ameliorate them. This is proximate to the position put forward by Michelle Greenwood and Harry Van Buren III. As such, they argue that:

To the extent that a vulnerable stakeholder group needs to trust in an organisation that it will not be exploited [that is, its commitments breached], there is a responsibility on the organisation to act in a non-opportunistic manner. These voluntary duties go beyond a negative promise not to take advantage of the other party; they suggest a positive guarantee that the rights and interests of the other party will be included in the final outcome. This is consistent with fiduciary duties ... ${ }^{104}$

The problem with this argument, however, is simply the assumption that, just because vulnerability to an untrustworthy actor causes harm, therefore the corporation has the responsibility to ameliorate it, by being trustworthy. But this does not follow. Putting cases of subordination aside, ${ }^{105}$ at least as a general principle: in a competitive market, with full information, where individuals can be held responsible and bear the cost for their choices to engage with corporations in general, then such individuals should be held responsible and bear the costs for engaging with untrustworthy corporations in particular. In short, we cannot have any plausible right to deal with a trustworthy actor, if we can be held responsible for choosing to deal with an untrustworthy one (or at least one we can neither rationally trust nor distrust).

This is because, at least under these conditions, the individual has full opportunity to 'cost in' any harm of vulnerability into their initial bargain. Presumably, she will strike a harder bargain with a corporation she cannot trust compared to one who is trustworthy. She may be quite prepared to reciprocally renege if justified. Furthermore, at least in such a market, there is the opportunity for corporations to compete over trustworthiness, offering alternatives for those who value (and are willing to pay) for it. Furthermore, and once again in such idealised conditions, simply preventing agents engaging with untrustworthy actors would be Pareto inefficient.

The strongest argument against this position is that, effectively, any such choice involves trading 'respect' for profit. As argued above, to deal with an untrustworthy actor - an actor who is indifferent about their commitments to you-is to be disrespected. Are we now arguing that it is just to be so disrespected? No. We are not

${ }^{104}$ Greenwood and Van Buren (2010: 434-5). They 'do not go as far as to say that trust creates a corresponding ethical duty for the organization.' However, they do not make clear the distinction between an 'ethical' and a 'voluntary' duty.

${ }^{105}$ See Section 5.2. 
justifying disrespect. We are merely saying that it is just that the relevant individual bear the cost of such disrespect. In part, this is because to do otherwise would disrespect the choice of that individual to enter into such an agreement, and to weigh up the costs and benefits thereof, for themselves. ${ }^{106}$

In sum, whilst it is always unjust for the other corporation to actually break a commitment (at least without justification or excuse), the fact of vulnerability to such injustice itself is not necessarily unjust. At least in idealised market conditions, ${ }^{107}$ it is a direct and foreseeable consequence of the agent's own choice, for which they should be held consequentially responsible. Any putative right to deal with a trustworthy corporation must arise because some other salient factor compromises either their choice or the fairness of its trade-offs.

\section{SALIENT VULNERABILITY: EXCEPTIONAL FACTORS THAT GROUND A RIGHT TO TRUSTWORTHINESS}

As a general principle, therefore, vulnerability to a corporation breaching a commitment by itself, even where not fully compensable, is not sufficient to ground a 'right to trustworthiness'. Some further factor is required to make it 'salient'. In this section, five such factors are put forward. In many cases, they will overlap, and we make no claim that they are exhaustive. However, they are at least five important and common factors, which both partially explain the intuitions behind much of our current public policy, and also ground arguments for new public policies.

\subsection{Market power}

In a competitive market with full information, where individuals can be held responsible for their choices (to invest, consume, lend, supply, or otherwise), a corporation will not be able to profit from being untrustworthy. ${ }^{108}$ This is to say that any failure to invest in various processes, signals, culture, and mechanisms that would

${ }^{106}$ In part, we are also assuming that such disrespect is not sufficient to undermine the dignity of the other agency. See Section 5.2.

${ }^{107}$ To clarify: the exceptions we set out are those that hold in non-idealised market conditions. For example, when a multinational wields significant market power (the first exceptional factor discussed below), this represents the condition of a non-ideal market; the ideal market has scope for competition between providers of goods and services.

${ }^{108}$ In other words, it is the case that in theory a corporation should not be able to profit from being untrustworthy. In the real world, of course, markets may be uncompetitive, contain information asymmetries, and have actors that cannot be held responsible for their choices. Thus, untrustworthy behaviour can sometimes be profitable, in the real world. 
increase trustworthiness, should be reflected in the market price of its goods, labour, or investment. Whilst corporations may appear to profit in any individual case of breaking a commitment, the very risk of doing so should be factored into the terms upon which it engaged with the relevant other agent in the first place. As such, the analysis in the preceding section should hold.

However, where a corporation has market power, a lack of trustworthiness may be an indirect way of reaping a market rent. To illustrate, let us take two examples: a monopoly with respect to service, and a monopsyny with respect to labour.

First, take the current contracts governing train services within the United Kingdom. Each train company is awarded something close to a monopoly with respect to a particular route or set of routes. Entirely unregulated, such a monopoly would naturally seek to reap rents by setting high prices for train fares. However, these prices are regulated by the government. Instead, the only avenue to accrue rents is to cut costs, including taking measures that will mean the trains are less reliable. In consequence, whilst train companies make commitments to run the trains on time, they have under-invested in the infrastructure to reliably keep those commitments. They are untrustworthy organisations in this respect. However, given the natural monopoly of the train route, consumers cannot easily turn to any competitor to incentivise either cheaper fares or a more reliable service. As such, the train company is able to reap a rent from its untrustworthiness. ${ }^{109}$

Secondly, take a small town that has only one big employer. The employer is close to being a monopsyny buyer of labour within the town. People may be able to migrate, but the transactions costs are high. We might assume that national regulations set the minimum wage of the corporation, and other working conditions. However, similar to the train company, the corporation knows that it can breach various commitments to its employees without any great fear of losing its workforce. It can take risks and drop processes, disregarding the consequences that it might fail to pay wages on time, fail to deliver on training and professional development, cut workplace safety, community events, etc. As such, insofar as the employer decreases costs and increases profit from such breaches, the employer is able to effectively reap a rent from its untrustworthiness. ${ }^{110}$

Assuming that any market rent is pro tanto unfair to those it adversely effects, other agents subject to such market power have a pro tanto moral right either to have the rent returned to them (for example, in lower prices, higher returns, or high wages) or for it to be invested in improving trustworthiness. Thus, in the former case, train

\footnotetext{
${ }^{109}$ On the rent-seeking behaviour of UK rail companies, see Wellings (2016). Bowman et al. (2013: 27) claim that their behaviour 'overlaps' with rent-seeking behaviour.

${ }^{110}$ See Taylor (2017: 49-50). De Beers, the diamond producer, is an example. It is the major employer of diamond workers in South Africa. It often operates in small towns where it provides the majority of employment (Dunning 2005).
} 
fares should be lowered to eliminate the rent, or they should receive the level of reliability of service consonant with the price of their train fares. In the latter case, wages might be raised, but more plausibly the workers have a right to access mechanisms that will increase the trustworthiness of the corporation: for example, through unionisation.

\subsection{Subordination}

In Section 3 we indicated that one of the harms that trustworthiness can ameliorate is subordination. Furthermore, we indicated that subordination was inherently unjust, and thus demanded amelioration, whether by trustworthiness or otherwise. It follows that any case of vulnerability that also amounts to subordination, grounds a right to trustworthiness (or an alternative ameliorating measure, if trustworthiness is otherwise inappropriate).

However, prima facie, one might think that the subsequent argument above in Section 3 establishing that, in general, vulnerability to corporations breaching a commitment does not necessarily ground a right to trustworthiness, applies a fortiori to the particular case of subordination. After all, in an ideal market, where such subordination would be a direct and foreseeable consequence of the agent's own choice, she has the opportunity to 'price it in' to her interaction; she can be held consequentially responsible for her situation.

This argument founders on two bases.

First, to reiterate, one of the wrongs perpetrated by subordination is not to the subordinated party. Instead, as kind of moral 'negative externality', it creates an illegitimate distribution of power within society. This, as it were, wrongs the state which has the sole authority to determine such a distribution, and/or everyone who has a right to a just distribution of power. As such, it does not lie within the right of any single agent to choose to create such a situation, regardless of her own preferences.

Secondly, as we noted above, as a general liberal principle, the state does have a strong reason to respect the agent's own free and responsible choices, even if these may lead to her own harm. However, this principle does not extend to the case of voluntarily entering into a position of subordination, regardless of the broader distributive consequences. This is because the very basic justification for this general principle is that it preserves an agent's dignity. However, since subordination necessarily degrades dignity: there is no reason to respect a choice to become subordinated. ${ }^{111}$

${ }^{111}$ This logic is seen in many areas of government intervention with choice, whether it be prostitution, drug use, slavery, self-harm, or suicide; and, most importantly, where public policy has changed on these 


\subsection{The absence of choice and the diminution of responsibility}

In our discussion so far, we have assumed that the relevant other agents have chosen to engage a corporation, and ceteris paribus can be held responsible for their consequent position. However, for a number of possible agents, this will not be the case. ${ }^{112}$ We can place such agents in three categories: 'agents with diminished capacity', 'third parties', and 'involuntary stakeholders'.

\subsubsection{First case: Diminished capacity}

First, sometimes a corporation chooses to engage someone directly, as a party to its activities, but who themselves lack the capacity to choose such an engagement, or whose capacity is contextually or partially compromised. ${ }^{113}$

In these cases, the relationship cannot be seen as merely contractual, in the sense that each party may seek to maximise their own advantage subject to their commitments (contractual or otherwise). By definition, the agent with sufficiently diminished capacity cannot have consented to such a situation, and, without consent, there cannot be a contract. Instead, these cases are fiduciary: this is to say, that the corporation is committed (implicitly or explicitly) to act on behalf of the incapacitated actor by exercising discretion with respect to their legitimate interest. ${ }^{114}$

The specific commitment that defines the fiduciary relationship is well recognised in law and moral philosophy. What is less well recognised is that, at least in cases where one lacks capacity, there is an additional obligation to be trustworthy with respect to that commitment. This is because, where the capacity to choose is absent, or otherwise compromised, the general reason to disregard the harm of vulnerability, argued in Section 3, disappears: such individuals cannot be held responsible for being

points, debates have focused upon establishing that some of these choices, if made under the right circumstances, do not diminish responsibility and thus undermine dignity.

${ }^{112}$ To clarify the sense of 'lacking choice' at issue in this section: this section discusses cases that are similar to the market power cases discussed above. But they are distinct, because they do not imply anything about the market power of the corporation. The stakeholders in question lack choice in whether to engage with the corporation, for other reasons.

${ }^{113}$ For example, for-profit corporations running retirement villages in Australia and New Zealand are in this kind of position with respect to the elderly people in its community suffering from dementia (see Petersen et al. 2017). Other candidates might be: children, those who lack full information, perhaps those who have been manipulated, and so on. However, someone in poverty does not generally fall into this category; neither does someone otherwise suffering background injustice. After all, why should the corporation have to bear the cost of re-distribution, especially when it may not even be a beneficiary of injustice? In these situations, choice is not necessarily absent or compromised, although options may be limited by background injustice. Instead, choice under poverty will generally fall under exceptions 1 and/or 2 .

${ }^{114}$ For example, a trustee exercising discretion to invest a beneficiary's property; or, a guardian exercising discretion in her decision about where to send her ward to school (see Newhouse 2014: 570). 
engaged with the corporation - in a fiduciary relationship or otherwise - and hence they cannot be responsible for being vulnerable to an untrustworthy corporation. By contrast, the corporation will have chosen to enter into the relevant relationship.

Most importantly, trustworthiness is required to ensure that fiduciary relationships are respectful. If a corporation runs nursing homes, then it must not merely try to meet its commitments to its residents (and/or compensate them for failing to do so), but must invest in reliably meeting those commitments, even at the expense of profit. Without such investment it shows an indifference to what it owes to its inhabitants, and thus disrespect. Assuming that some, if not many, such inhabitants have diminished capacity, such disrespect cannot be excused as 'part of the deal'.

\subsubsection{Second case: Third parties}

Secondly, in almost any situation, a corporation will be surrounded by what we will call 'third parties': that is, those whom a corporation does not choose to engage directly, as a party to its activities, and whose interests are not under the legitimate control of the corporation, but who are vulnerable to harm caused by the misuse or negligent use of the corporation's powers in pursuing these activities. For example: the Dounreay nuclear plant in Scotland leaked radioactive contamination for over two decades between 1963 and 1984. Tens of thousands of radioactive particles from old reactors contaminated the shoreline and seabed, thereby harming the interests of a third party, the local community. ${ }^{115}$

Prima facie, despite the ubiquity of third parties, our argument so far might seem to suggest that they have a right to deal with trustworthy corporations. Admittedly, by definition, there are no specific commitments between the corporations and third parties (or else, they would no longer be third parties). However, corporations can be said at least to be implicitly committed to respecting the general system of private rights and duties, paradigmatically property rights. This is a commitment we might understand as owed either to the state or to everyone in general. As such, corporations can be trustworthy or not, with respect to such commitments, and trusted by third parties to do so.

Thus, since third parties do not choose to be vulnerable to corporations breaching these commitments, do third parties not have a default right to corporations being trustworthy with respect to their interests?

No. It is undoubtedly a harm to a third party to be vulnerable to an untrustworthy corporation. However, it is not necessarily unjust. The value of one's private rights (their pros and cons) is always, partially, a function of their surrounding environment: its positive and negative features. Assuming these features are 'costed in' to the value

\footnotetext{
${ }^{115}$ See Edwards (2011).
} 
of the private rights, there is nothing inherently unjust about them. And this logic applies just as much to ending up exposed to a risky, disrespectful neighbour as much as others negatives. This is not to say that the government might not legislate that specific entities or specific activities require a certain added degree of reliability (for example, where the likely breach of commitment might lead to a grossly incompensable harm: death or severe injury), or that the other party might be bankrupt and unable to compensate (for example, third party car insurance), or that the third party is engaging in activities that require additional security (for example, a military installation). In short, whilst a third party may not have chosen to be vulnerable to a corporation breaching a commitment, putting aside other public policy imperatives, it is still just that the third party bear the cost of such vulnerability, since the right to create such vulnerabilities and the risk of being so exposed can be assumed to be costed into the distributive system in general.

\subsubsection{Third case: Involuntary stakeholders}

Finally, our analysis of the first two cases, helps us deal with a final category: involuntary 'stakeholders'. In some situations, an agent who would otherwise be a third party, involuntarily becomes what we might call a 'stakeholder' with respect to the corporation. ${ }^{116}$ More precisely, the corporation acquires a commitment with respect to the interests of the other actor. This may not be a fiduciary relationship in the sense that the corporation is required to act on behalf of the stakeholder and promote its interests without qualification. Instead, it may merely need to take such interests into 'account', to be 'weighed' against other relevant interests in a decision. ${ }^{117}$

\footnotetext{
${ }^{116}$ Clarkson (1994: 5) discusses involuntary stakeholders. However, he says that they are stakeholders who are 'placed at risk as a result of a firm's activities'. Without the element of risk, there is no stake (that is, there is nothing to be lost). Clarkson intends to use the term 'risk' to denote 'stake', to narrow the field to those with legitimate claims on the firm. In contrast, we want to say that involuntary stakeholders are not simply those who are placed at risk by the corporation's activities; they are those who have also not chosen to directly engage with the corporation, and whose interests are nevertheless under the legitimate control of the corporation. Our definition is closer to Langtry's definition (1994: 433) of a stakeholder as someone whose well-being the corporation is significantly responsible for, or who holds a moral or legal claim on the corporation. See Mitchell et al. (1997) for a tour through the thorny thickets of stakeholder theory, and who and what counts.

${ }^{117}$ For example, consider the outsourcing of a huge range of local council services in the UK, from street-cleaning to waste collection, recycling to maintenance, to corporations like Serco, Capita, and Veolia. Elected local councils chose to legally contract out these services to these corporations, so they legitimately control the interests of the local communities in these domains. This paper contends that, when elected local councils chose to outsource these services to these corporations, the corporations acquired commitments with respect to the interests of the local community, and the local community became a stakeholder with respect to the corporation. This is not a fiduciary relationship, since the corporations are not required to act on behalf the local community, and promote its interests without qualification. Instead, it may merely need to take its interests into 'account' and 'weigh' them against
} 
Applying our analysis above, therefore: involuntary stakeholders lie in an analogous position to those with diminished capacity. There is no reason they should bear the cost of vulnerability to an untrustworthy actor, including the disrespect of its indifference. The most important difference, however, is that corporations must take involuntary stakeholders to be the appropriate authority about what their interests are. Unlike many cases of diminished capacity, they are not in a guardianship-style situation. As such, any commitment to take their interests into account, and to do so trustworthily, also entails a commitment to processes of consultation and deliberation, to ensure that the corporations adopt the stakeholder's own view of their own interests.

\subsection{Preserving systemic or social trust}

Until now we have implicitly assumed that the only agent whose trustworthiness is at issue is the relevant corporation, and the only trust relation at issue is that between the corporation and agents' vulnerability to it (as if such trust and trustworthiness were hermetically sealed within particular trust relationships). However, trust is rarely so individualised. Often, we (rationally) trust an individual agent, or corporation, on the basis of very little evidence specific to their own character; instead, we trust such an individual agent or corporation, on the basis of their membership of system or group that we trust in general. ${ }^{118}$ Furthermore, as sociologists have argued, we trust such an individual, or groups of individuals, because they operate within a set of social institutions that we trust. ${ }^{119}$

No corporation is an island. This is recognised by the latest UK Corporate Governance Code (2018), which states that, 'Companies do not exist in isolation. Successful and sustainable businesses underpin our economy and society by providing employment and creating prosperity. To succeed in the long term, directors and the companies they lead need to build and maintain successful relationships with a

other relevant interests in deciding what to do. However, if other interests were prioritised by the corporations, or if they were to fail, the risk to local communities would be high: there would be no waste collection, for example, and that would be a serious health hazard to the local community. See Blair (2014) for the view that interests other than the interests of shareholders can be weighed, and sometimes prioritised, by the board in making a decision. See also Kaufman \& Englander (2005).

${ }^{118}$ Researchers call this form of nonspecific group trust 'generalised' or 'social' trust. For how factors such as inequality, diversity, or perceived corruption affect social trust, see Dinesen (2012, 2013), Rothstein $(2013,2017)$, and Uslaner $(2002,2012)$. Social trust (if not simply equivalent to) is related to 'social capital', which Sztompka (1998: 20) defines as 'a bet on the future contingent actions of others'. For more on social capital, see Castiglione et al. (2008), Larsen (2013), and Putnam et al. (1993).

${ }^{119}$ See footnote 12 for references on sociological research on 'institutional' trust. 
wide range of stakeholders. ${ }^{120}$ Simply put, the actions of individual corporations have wider effects on society. On top of this, though, the actions of one corporation have the potential to affect the trust held toward other corporations (perhaps those of a similar role) or even the corporate world as a whole. Just as no corporation is an island in the function it performs, no corporation is an island in how trustworthy it appears.

In part, we trust systems, groups, or societies because of the qualities of individual members. Hence, the (un)trustworthiness of one individual member of the group, whether it be a corporation or a person, will partially determine the rationality of (dis)trusting others within the group. As such, the trustworthiness, or not, of any one corporation, is liable to affect the trust relations of corporations and other agents within the group or system. Does any right or obligation follow from this state of affairs?

In general, in a competitive market situation, the answer is 'no', even if a corporation 'freerides' for a period of time on generalised trust.

As discussed above, trustworthiness is often costly. ${ }^{121}$ In a free market, therefore, ceteris paribus, corporations should be able to compete over their trustworthiness, allowing other agents to choose the appropriate risk/reward payoff they prefer. Hence, a market may exist with a degree of generalised trust with respect to certain commitments. However, a gap in the market may exist for a competitor that is less reliable but can offer much lower prices. As they enter the market, customers may make similar assumptions about their reliability, and hence trustworthiness, as for previous players. As such, for a brief period of time, the new player may even freeride on the basis of such trust, bringing in more customers than they might otherwise expect. However, predictably, the corporation will ultimately disappoint these expectations, as its true level of reliability is revealed. Customers may even feel 'betrayed', but so long as the corporation did not make a commitment to levels of trustworthiness it could never expect to meet, this betrayal is misplaced.

In this situation, the market should properly reveal and price the trustworthiness of the new corporation. Now this may impact the generalised trust of other corporations. However, in this situation, it is up to those corporations to adapt: either to differentiate themselves on the basis of trustworthiness, or to compete with the new player on price.

An example of these dynamics would be the entry of new 'low-cost' airlines into the European market over the last twenty years. Airlines like Ryanair and EasyJet offered cheap flights compared to traditional operators like British Airways, but

${ }^{120}$ FRC (2018: 1).

${ }^{121}$ See Section 2.4 . 
also offered a less reliable service. Because customers were in the long term willing to bear the risk of unreliability, as long as they paid a reduced cost, a market for these airlines developed over time, separate from the traditional airlines, who then took to distinguishing themselves from the low-cost ones by putting a premium on their comparative reliability. Each type of airline then came to serve a different market. The unreliability of one type did not have to affect the perceived general trustworthiness of the other. ${ }^{122}$

The point is that, in general in a market situation, the existence of generalised trust is not some sacred cow that must be protected in the face of new business strategies. If the existence of a market with great levels of generalised trust is the most socially efficient, then ceteris paribus regulators should seek to achieve such a situation. However, if left unregulated for such utilitarian reasons, no single competitor has a moral responsibility to uphold such generalised trust by unprofitable investments in reliability. No one has a right to such trustworthiness. Ultimately, one might say that in such situations the generalised trust is ultimately poorly founded, as corporations can be expected to act contrary to such expectations, and there is no obligation to preserve poorly founded trust.

Having defined this general principle, there exist two important exceptions.

First, there can be a right to deal with trustworthy corporations in cases where systemic trust is both essential to the market operating, and the existence of that market is of critical importance. For example, systemic trust is very important when there is high information asymmetry between corporations and consumers about the

${ }^{122}$ An anonymous reviewer suggests that low-cost airlines, rather than being less reliable than traditional ones, are simply 'no-frills'. In other words, they may get you to your destination on time, but that is all that should be expected of them. As such, they are not less reliable than traditional airlines. However, it must be emphasised that the question is how reliable low-cost airlines are with respect to meeting their various commitments, including their implicit ones. While it is difficult to find peer-reviewed data on this point, analysis and commentary surrounding Ryanair's 2017 cancellation of numerous flights due to pilot shortages, highlights the unreliability of budget airlines in comparison to traditional ones, in respect of meeting their various implicit and explicit commitments. Remarks from Andrew Charlton (an aviation analyst) on Ryanair's recent problems with a shortage of standby pilots, vividly bring out a point emphasised throughout this paper: that reliability has a price. Budget airlines like Ryanair have a 'lean structure', meaning they have little room for manoeuvre when hit with problems, as was the case recently with its shortage of standby pilots; 'Ryanair runs an extraordinarily tight ship. When something like this happens they haven't got much of a margin for error' (Beesley et al. 2017). So, Ryanair lacks the internal features (per Section 2.4) that traditional airlines have, that would otherwise enable them to reliably meet commitments, even in case of setback. Ryanair's lack of internal reliability extended to failing to advise and compensate customers when their flights were cancelled. The Civil Aviation Authority (the airline regulator) was then required to prompt Ryanair to acknowledge its statutory commitments; an example of the costs of corporate unreliability being borne by the state (see Lynam 2017, Topham 2017, Treanor et al. 2017). Treanor et al. describe the measures that Ryanair took to avoid meeting this commitment, with call-centre staff being instructed to mislead customers. See also Ahluwalia (2017). 
reliability of the relevant product. Left unregulated, the market for more reliable goods may collapse, since consumers cannot distinguish them from unreliable goods. When the market is for 'lemons' (that is, second-hand cars), ${ }^{123}$ this may be socially inefficient, but there is no deep injustice at stake: no moral right to trustworthy second-hand car dealers, nor a duty for the dealers to be trustworthy, enforceable by law. However, when the market is for baby milk formula (as per events in China in 2008), ${ }^{124}$ then the collapse of the market undermines access to a basic good, which is an injustice. ${ }^{125}$

A similar dynamic arises, not when there is high information asymmetry, but when the market for the critical basic good relies upon a high degree of coordination, such as in the banking system where the financial product being sold to one consumer depends upon the confidence of other consumers. ${ }^{126}$

In both the information asymmetry and coordination situations, well-founded distrust in one corporation is liable to metastasise into distrust of other corporations, which may well become a self-fulfilling belief, as distrust itself inhibits the ability of other corporations to fulfil their commitments, risking systemic collapse. In such markets, corporations have an obligation to be trustworthy, and to lobby, support, and fund structures that prevent such contagion. ${ }^{127}$ It is unconscionable to seek to profit from untrustworthy behaviour in such domains. Instead, corporations should be held responsible not merely for so acting, but also for failing to take proactive steps to prevent such behaviour: diagnosing and ameliorating perverse incentives as they arise.

Secondly, untrustworthiness by corporations, or systemic distrust caused by some untrustworthy corporations, but growing to encapsulate others, can also potentially hollow out the generalised social trust that allows society to function. For example, if the corporate world is seen not to pay its fair share of tax, then citizens will be much less inclined to pay their taxes. Citizens will generally follow norms of reciprocity: it does not make sense to do your bit in paying for social goods if you perceive that others are not going to do the same. In circumstances where the corporate system is seen as being allowed, by the government, to avoid fulfilling its commitments, this will generate perceptions of unequal status and institutional corruption. Where public institutions are seen to uphold inequality, this negatively impacts on generalised social

\footnotetext{
${ }^{123}$ See Akerlof (1970).

${ }^{124} \operatorname{Orr}(2008)$.

${ }^{125}$ Deutsch (1985) provides an account of distributive justice in terms of basic goods.

${ }^{126}$ On the contribution of bank runs to the global financial crisis, see Shin (2009) and Ivashina \& Scharfstein (2010).

${ }^{127}$ Thompson argues that, if compliance with commitments are currently implausible or existentially risky, corporations ought to campaign to create systemic measures that make them plausible (Thompson 2003: 310).
} 
trust. ${ }^{128}$ Similarly, when corruption is seen as normal, this makes corrupt behaviour more likely. ${ }^{129}$ As such, where there is a threat of undermining generalised social trust, corporations can be obligated to be trustworthy, and to take steps to prevent systemic untrustworthiness, for the sake of preserving the social fabric. ${ }^{130}$

\subsection{Political power}

Finally, some corporations do not merely accumulate market power or the power to harm others, but achieve power to influence aspects of their own regulatory, and political institutions. Such power threatens two distinct possible harms that demand amelioration via trustworthiness or other means.

First, and most obviously, where a corporation's power means it is able to subordinate the state, then the very legitimacy of the state is threatened. To reiterate: a relationship of subordination would not arise merely because the corporation might breach its commitments and harm the state, or society more generally. Rather, it does when (a) the state (through its agents) cannot rationally rely upon the corporations to keep a commitment, and (b) the state understands itself to be vulnerable to being coerced into performing an action it would not otherwise be obligated to perform, by the mere threat of the other agent breaching its commitment. ${ }^{131}$

Such subordination clearly disrupts the rightful distribution of power within a society, undermines the authority of the state, and at least metaphorically corrodes the state's own 'dignity'. ${ }^{132}$

Secondly, however, the power to influence the state, not necessarily amounting to subordination, can also be a threat to the state's legitimacy. This threat arises where

\footnotetext{
${ }^{128}$ See Charron \& Rothstein (2014), Rothstein (2013, 2017), Uslaner (2012), and Section 5.5.

${ }^{129}$ Gustavson \& Rothstein (2013: 46).

${ }^{130}$ Along these lines, corporations can sometimes be responsible for systematic injustice against members of a particular ethnic group or religion, for example, by carrying out actions or endorsing policies that systematically favour certain groups at the expense of others. If this kind of injustice becomes seen as permitted by the broader society (if the justice system fails to prevent it being carried out), then this can undermine systemic social trust within that community, leading to the society fracturing. Research suggests that societies that actively pursue egalitarianism have higher levels of generalised social trust. Rothstein (2013: 1019, citing De Cremer et al. 2005: 402) concisely summarises the mechanism behind this: " "Being treated fairly and respectfully will install among group members a feeling of inclusiveness" from which also follows increased social trust.' (In addition to Rothstein and Uslaner cited above, see Trägårdh 2013). Thanks to a reviewer from the British Council for pressing for further elaboration on this point.

${ }^{131}$ One might think that the power of corporate money in the form of political donations puts American political institutions in this position and prevents governments from being responsive to citizens (Whitehouse \& Stinnett 2017).

${ }^{132}$ See Kantorowicz (1957).
} 
such power is able to undermine the integrity of the state-its officers and its institutions - most obviously via corruption. ${ }^{133}$

Corruption arises at the individual level, as the abuse of entrusted power for private gain. ${ }^{134}$ However, it also arises at the institutional level, as defined by Lawrence Lessig:

[W] hen there is a systemic and strategic influence which is legal, or even currently ethical, that undermines the institution's effectiveness by diverting it from its purpose or weakening its ability to achieve its purpose, including, to the extent relevant to its purpose, weakening either the public's trust in that institution or the institution's inherent trustworthiness. ${ }^{135}$

Whilst the details of these definitions are disputed, ${ }^{136}$ the broader moral point is clear. Where anyone, including a corporation, causes an officer or an institution to abuse its powers for illegitimate purposes, then it corrodes the trustworthiness and legitimacy of such offices and institutions. However, and precisely in respect of our immediate point, this also arises where citizens cannot rely upon corporations or public agents not to engage in corruption. This is sufficient to undermine the trustworthiness of the public agent, and thus sufficient to corrode their legitimacy. In part, this is because the norm of reciprocity is at play: if citizens cannot rationally rely upon public agents to fulfil their public duties (to not be corrupt), then citizens may acquire a justification to renege on their duty to obey such public agents (in order to protect themselves from being taken advantage of).

Trustworthiness ameliorates both of these ills: it eliminates subordination, and it does not only prevent corruption, but the threat of corruption. Even if public agents might be susceptible to corruption, the trustworthiness of corporations would at least mean the public would rest assured they will not have corporate partners in crime.

\footnotetext{
${ }^{133}$ Work on the notion of 'public integrity', as distinct from corruption, is quite underdeveloped. For this reason, we focus here on the case of corruption. However, most of the few authors who have written on the topic agree that the integrity of public institutions, and individual public officers, is not simply the absence of corruption. Hence, it can be undermined by corrupt power in non-corrupt ways. Furthermore, insofar as one accepts the further claim that undermining any element of public integrity (not just via corruption) threatens public legitimacy, then the argument applied below with respect to corruption, applies more generally. See Brock (2014), Hardi et al. (2015), Heywood \& Rose (2015), Heywood et al. (2017), Huberts (2014), Kirby (2018), Montefiore \& Vines (1999), and Philp (2007).

${ }^{134}$ Pope (1997), Transparency International (2018), and Mungiu-Pippidi (2015: 3).

${ }^{135}$ Lessig, (2013: 553).

${ }^{136}$ See Philp (1997) and Amit et al. (2017).
} 


\section{CONCLUSION}

Trust is good, but control is better.

Vladimir Lenin (1870-1924)

As political constituencies around the globe react to the 'crisis of trust' - not just with respect to corporations, but also government, the media, and elites - there is a temptation to agree with Lenin's claim. There is a desire, in no large part born of legitimate frustration and injustice, not merely to reform but to 'take back control'. However, as argued in this essay, at least with respect to corporations, well-founded trust is incredibly valuable: it allows the social efficiency of capitalism, decreases its risks, allows for respect, validates reciprocity, and safeguards dignity and the rightful distribution of power against subordination. Yes, some measures to achieve trustworthiness in corporations, at least as we have defined it, are somewhat 'controlling', and will require regulation, vigilance, and threats of punishment. However, many measures are not: instilling values, culture, and purpose to corporations; increasing the social capital and rewards of trustworthy behaviour; structuring markets in a way that avoids 'races to the bottom' with respect to breaching commitments; ensuring that appropriate information about a corporation's reliability is available to vulnerable agents.

If our only reaction to this crisis of trust is a programme of control, then we would lose much of the value that such trustworthiness can create, but which is out of the reach of purely coercive, controlling regimes.

As we have argued, however, building well-founded trust is costly. It is not enough to simply laud such trust's value. We must also distribute the duties to make it happen, and the responsibilities to bear its cost. This paper has only sought to explore one aspect of that set of duties and responsibilities: the duty of corporations themselves to be trustworthy, and bear the costs of such trustworthiness. It has rejected the idea that there is any general duty to be trustworthy, but set out five distinct cases where particular duties arise: market power, subordination, the absence of choice, the preservation of systemic trust, and political power. Perhaps if corporations take up these duties, whether by their own volition or by external encouragement, then we might see that trust is good, control is better, trustworthiness is best.

\section{REFERENCES}

Ahluwalia, R. (2017), 'The Best (and Worst) Airlines in the World', The Independent. http://www.independent.co.uk/travel/news-and-advice/ryanair-easyjet-worst-airlines-in-world-new-rankings-research-airhelp-quality-service-delay-a7791151.html 
Akerlof, G. A. (1970), 'The Market for "Lemons": Quality Uncertainty and the Market Mechanism', The Quarterly Journal of Economics, 84: 488-500. https://doi.org/10.2307/1879431

Allard-Tremblay, Y. (2015), 'Trust and Distrust in the Achievement of Popular Control', The Monist, 98 : 375-90. https://doi.org/10.1093/monist/onv019

Alonso, F. M. (2009), 'Shared Intention, Reliance, and Interpersonal Obligations', Ethics, 119: 444-75. https://doi.org/10.1086/599984

Alonso, F. M. (2014), 'What is Reliance?', Canadian Journal of Philosophy, 44: 163-83. https://doi.org/1 $0.1080 / 00455091.2014 .919722$

Amit, E., Koralnik, J., Posten, A.-C., Muethel, M. \& Lessig, L. (2017), 'Institutional Corruption Revisited: Exploring Open Questions within the Institutional Corruption Literature', Southern California Interdisciplinary Law Journal, 26, 447-595.

Andrews, E. L. (1998), 'Volkswagen to Create \$12 Million Fund for Nazi-era Laborers', The New York Times.

https://www.nytimes.com/1998/09/11/world/volkswagen-to-create-12-million-fund-for-nazi-eralaborers.html

Ariely, D. \& Wertenbroch, K. (2002), 'Procrastination, Deadlines, and Performance: Self-control by Precommitment', Psychological Science, 13: 219-22. https://doi.org/10.1111/1467-9280.00441

Arrow, K. J. (1974), The Limits of Organization (New York, W. W. Norton).

Baier, A. (1986), 'Trust and Antitrust', Ethics, 96: 231-60. https://doi.org/10.1086/292745

Beesley, A., Powley, T. \& Hollinger, P. (2017), 'Ryanair: Turbulent Times for Low-cost Pioneer', Financial Times. https://www.ft.com/content/45311cb0-9f7a-11e7-8cd4-932067fbf946

Binham, C. (2013), 'RBS Pays £390m to Settle Libor Probe', Financial Times. https://www.ft.com/content/fc3dbb14-7060-11e2-ab31-00144feab49a

Birsch, D. \& Fielder, J. (1994), The Ford Pinto Case: A Study in Applied Ethics, Business, and Technology (Albany, NY, State University of New York Press).

Bishop, B. (2017), 'Perspective | Americans Have Lost Faith in Institutions. That's Not Because of Trump or "Fake News"', Washington Post.

https://www.washingtonpost.com/posteverything/wp/2017/03/03/americans-have-lost-faith-ininstitutions-thats-not-because-of-trump-or-fake-news/

Black, O. (2004), 'Reliance and Obligation', Ratio Juris, 17: 269-84.

https://doi.org/10.1111/j.1467-9337.2004.00269.x

BlackRock's Mission Statement on Sustainability (2018), BlackRock. https://www.blackrock.com/corporate/literature/publication/blk-sustainability-mission-statementweb.pdf [accessed 26 August 2018].

Blair, M. (2014), 'Boards of Directors Under a Team Production Model', in J. Hill \& R. Thomas (eds) Research Handbook on Shareholder Power (Cheltenham, Edward Elgar), 249-68 .

Bohnet, I., Frey, B. S. \& Huck, S. (2001), 'More Order with Less Law: On Contract Enforcement, Trust, and Crowding', American Political Science Review, 95(1): 131-44. https://doi.org/10.1017/S0003055401000211

Bok, S. (1978), Lying : Moral Choice in Public and Private Life, 1st edn (New York, Pantheon Books).

Bowman, A., Folkman, P., Froud, J., Johal, S., Law, J., Leaver, A., Moran, M., et al. (2013), The Great Train Robbery: Rail Privatisation and After, Centre for Research on Socio-Cultural Change, University of Manchester.

http://hummedia.manchester.ac.uk/institutes/cresc/sites/default/files/GTR $\% 20$ Report $\% 20$ final $\%$ 205\%20June $\% 202013$.pdf

Bratton, W. W. \& Wachter, M. L.(2010), 'The Case Against Shareholder Empowerment', University of Pennsylvania Law Review, 158: 653-728.

Brocas, I., Carillo, J. \& Dewatripont, M., (2004), 'Commitment Devices under Self-control Problems: An Overview’, in I. Brocas \& J. Carillo (eds) The Psychology of Economics Decisions, Volume 2: Reasons and Choices (Oxford, Oxford University Press), 49-66. 
Brock, G., (2014), 'Institutional Integrity, Corruption, and Taxation', Edmond J. Safra working papers 39. https://doi.org/10.2139/ssrn.2408183

Carney, M. (2013), 'Rebuilding Trust in Global Banking', speech presented at the 7th Annual Thomas d'Aquino Lecture on Leadership, 25 February, Lawrence National Centre for Policy and Management, Richard Ivey School of Business, Western University, London, Ontario.

https://www.bis.org/review/r130226c.pdf

Carter, I. (2008), 'How are Power and Unfreedom Related?', in Republicanism and Political Theory C. Laborde \& J. Maynor (eds) (Malden, MA, Blackwell), 58-82

Castiglione, D, van Deth, J. \& Wolleb, G. (eds) (2008), Handbook of Social Capital (Oxford, Oxford University Press).

Chasan, E. (2017), 'BlackRock Wields its \$6 Trillion Club to Combat Climate Risks', Bloomberg.com. https://www.bloomberg.com/news/articles/2017-12-08/blackrock-wields-its-6-trillion-club-tocombat-climate-risks

Charron, N. \& Rothstein, B. (2014), Social Trust, Quality of Government and Ethnic Diversity. An Empirical Analysis of 206 Regions in Europe,working paper 20, The Quality of Government Institute University of Gothenburg.

Chau, D. (2018), 'AMP Releases \$615m Damage Control Plan, Lowers Profit Expectations', ABC News. http://www.abc.net.au/news/2018-07-27/amp-damage-control-plan-lower-profit-expectations/ 10042530

Child, J. \& Möllering, G. (2003), 'Contextual Confidence and Active Trust Development in the Chinese Business Environment', Organization Science, 14(1): 69-80. https://doi.org/10.1287/orsc.14.1.69.12813

Clarkson, M. (1994), A Risk Based Model of Stakeholder Theory. Proceedings of the Second Toronto Conference on Stakeholder Theory (Toronto, Centre for Corporate Social Performance and Ethics, University of Toronto).

Coates, I. V. \& Srinivasan, S. (2014), 'SOX After Ten Years: A Multidisciplinary Review', Harvard Law and Economics discussion paper 758, Harvard Law School and Harvard Business School. https://papers.ssrn.com/abstract $=2343108$

Coleman, J. S. (1990), Foundations of Social Theory (Cambridge, MA, Belknap Press of Harvard University Press).

Collins, S. (2013), 'Collectives' Duties and Collectivisation Duties', Australasian Journal of Philosophy, 91: 231-48. https://doi.org/10.1080/00048402.2012.717533

Cooper, C. (2016), 'Gove Urges Referendum Voters to Take Back Control from EU "Elites" ', The Independent.

http://www.independent.co.uk/news/uk/politics/eu-referendum-michael-gove-urges-voters-to-takeback-control-from-europes-unaccountable-elites-a7064711.html

D’Arcy, E. (1963), Human Acts: An Essay in Their Moral Evaluation (Oxford, Clarendon Press).

D’Cruz, J. (2015), 'Trust, Trustworthiness, and the Moral Consequence of Consistency', Journal of the American Philosophical Association, 1: 467-84. https://doi.org/10.1017/apa.2015.3

Darwall, S. L. (2006), The Second-person Standpoint: Morality, Respect, and Accountability (Cambridge, MA, Harvard University Press).

Dasgupta, P. (1988), 'Trust as a Commodity', in D. Gambetta (ed.) Trust: Making and Breaking Cooperative Relations (Oxford, Blackwell), 49-72.

de Beer, E. S. (ed.) (2010), The Correspondence of John Locke, Volume 1: Introduction, Letters 1-461 (Oxford, Oxford University Press).

de Bruin, B. (2015), Ethics and the Global Financial Crisis: Why Incompetence is Worse than Greed (Cambridge, Cambridge University Press). https://doi.org/10.1017/CBO9781139237093

De Cremer, D., Tyler, T. R. \& Ouden, N. den. (2005), 'Managing Cooperation via Procedural Fairness: The Mediating Influence of Self-other Merging', Journal of Economic Psychology, 26: 393-406. https://doi.org/10.1016/j.joep.2004.12.004 
Deutsch, M. (1985), Distributive Justice: A Social-psychological Perspective (New Haven, CT, Yale University Press).

Dinesen, P. T. (2012), 'Does Generalized (Dis)Trust Travel? Examining the Impact of Cultural Heritage and Destination-country Environment on Trust of Immigrants', Political Psychology, 33: 495-511. https://doi.org/10.1111/j.1467-9221.2012.00886.x

Dinesen, P. T. (2013), 'Where You Come From or Where You Live? Examining the Cultural and Institutional Explanation of Generalized Trust Using Migration as a Natural Experiment', European Sociological Review, 29(1): 114-28. https://doi.org/10.1093/esr/jcr044

Dinsmore, B. (2010), 'The Citi Blog-Our Promise to our Customers', Citi Blog. https://blog.citigroup.com/2010/05/our-promise-to-our-customers

Dunning, T. (2005), 'Resource Dependence, Economic Performance, and Political Stability', Journal of Conflict Resolution, 49: 451-82. https://doi.org/10.1177/0022002705277521

Edey, M. (2009), 'The Global Financial Crisis and Its Effects', Economic Papers: A Journal Of Applied Economics and Policy, 28(3): 186-95. https://doi.org/10.1111/j.1759-3441.2009.00032.x

Edwards, R. (2011), 'Scottish Nuclear Leak "Will Never Be Completely Cleaned Up”'. The Guardian. http://www.theguardian.com/environment/2011/sep/21/scottish-nuclear-leak-clean-up

Farber, D. A., \& Matheson, J. H. (1985), 'Beyond Promissory Estoppel: Contract Law and the "Invisible Handshake", The University of Chicago Law Review, 52: 903-47. https://doi.org/10.2307/1599520

FRC (2016a), Corporate Culture and the Role of Boards (London, Financial Reporting Council). https://www.frc.org.uk/getattachment/3851b9c5-92d3-4695-aeb2-87c9052dc8c1/Corporate-Culture-andthe-Role-of-Boards-Report-of-Observations.pdf

FRC (2016b), UK Corporate Governance Code (London, Financial Reporting Council). https://www.frc.org.uk/getattachment/ca7e94c4-b9a9-49e2-a824-ad76a322873c/UK-Corporate-GovernanceCode-April-2016.pdf)

FRC (2018), UK Corporate Governance Code (London, Financial Reporting Council). https://www.frc.org.uk/getattachment/88bd8c45-50ea-4841-95b0-d2f4f48069a2/2018-UK-CorporateGovernance-Code-FINAL.PDF

Fricker, M. (2012), 'Group Testimony? The Making of a Collective Good Informant', Philosophy and Phenomenological Research, 84: 249-76. https://doi.org/10.1111/j.1933-1592.2011.00565.x

Friedrich, D., \& Southwood, N. (2011), 'Promises and Trust', in H. Sheinman (ed.) Promises and Agreement: Philosophical Essays (Oxford, Oxford University Press), 275-92. https://doi.org/10.1093/acprof:oso/9780195377958.003.0012

Fukuyama, F. (1995), Trust: The Social Virtues and the Creation of Prosperity (London, Hamish Hamilton).

Gambetta, D. (1988), 'Can We Trust Trust?', in D. Gambetta (ed.) Trust: Making and Breaking Cooperative Relations (Oxford, Blackwell), 213-37.

Gaus, G. (2003), 'Backwards Into the Future: Neorepublicanism as a Postsocialist Critique of Market Society', Social Philosophy and Policy, 20: 59-91. https://doi.org/10.1017/S0265052503201047

Gharad, B., Karlan, D. \& Nelson, S., (2010), 'Commitment Devices', Annual Review of Economics, 2(1): 671-98.

Gilbert, M. (1992), On Social Facts (Princeton, NJ, Princeton University Press).

Gilbert, M. (2006), A Theory of Political Obligation: Membership, Commitment, and the Bonds of Society (Oxford, Oxford University Press). https://doi.org/10.1093/0199274959.001.0001

Gilbert, M. (2013), Joint Commitment: How We Make the Social World (Oxford, Oxford University Press). https://doi.org/10.1093/acprof:oso/9780199970148.001.0001

Gordon, S. (2014), 'One in Five Suppliers Bullied, Says UK Small Business Lobby', Financial Times. https://www.ft.com/content/fd18d618-8058-11e4-872b-00144feabdc0 
Gordon, S. (2018), 'Large UK Companies Accused of "Supply Chain Bullying" ', Financial Times. https://www.ft.com/content/d1b277f0-5f33-11e8-9334-2218e7146b04

Granovetter, M. S. (1973), 'The Strength of Weak Ties', American Journal of Sociology, 78: 1360-80. https://doi.org/10.1086/225469

Granovetter, M. (1985), 'Economic Action and Social Structure: The Problem of Embeddedness', American Journal of Sociology, 91: 481-510. https://doi.org/10.1086/228311

Greenwood, M., \& Van Buren, H. J. (2010), 'Trust and Stakeholder Theory: Trustworthiness in the Organisation-Stakeholder Relationship', Journal of Business Ethics, 95: 425-38. https://doi.org/10.1007/s10551-010-0414-4

Gustavson, M., \& Rothstein, B. (2013), 'Can Auditing Generate Trust? The Organization of Auditing and the Quality of Government'. Trust and Organizations (New York, Palgrave Macmillan), 41-63. https://doi.org/10.1057/9781137368812_3

Hanna, J. (2014), 'The Costs and Benefits of Sarbanes-Oxley', Forbes. https://www.forbes.com/sites/ hbsworkingknowledge/2014/03/10/the-costs-and-benefits-of-sarbanes-oxley/

Hanratty, P. (1997), The Wallis Report on the Australian Financial System: Summary and Critique (No. 16), Economics, Commerce and Industrial Relations Group, Canberra.

https://www.aph.gov.au/About_Parliament/Parliamentary_Departments/Parliamentary_ Library/pubs/rp/RP9697/97rp16

Hardi, P., Heywood, P. \& Torsello, D., (2015), Debates of Corruption and Integrity: Perspectives from Europe and the US (Houndsmills, Palgrave Macmillan).

Hawley, K. (2014), 'Trust, Distrust and Commitment', Noûs, 48(1): 1-20. https://doi.org/10.1111/nous. 12000

Heaney, S. (1996), Crediting Poetry: The Nobel Lecture, 1st edn (New York, Farrar Straus Giroux).

Helm, B. W. (2014), 'Trust as a Reactive Attitude', in D. Shoemaker \& N. Tognazzini (eds) Oxford Studies in Agency and Responsibility, Volume 2 (Oxford, Oxford University Press), 187-215. https://doi.org/10.1093/acprof:oso/9780198722120.003.0010

Heywood, P. \& Rose, J. (2015), 'Curbing Corruption or Promoting Integrity? Probing the Hidden Conceptual Challenge', in P. Hardi, P. Heywood \& D. Torsello (eds) Debates of Corruption and Integrity: Perspectives from Europe and the US (Houndsmills, Palgrave Macmillan), 102-19.

Heywood, P., Marquette, H., Peiffer, C. \& Zúñiga, N. (2017), 'Integrity and Integrity Management in Public Life', European Commission ANTICORPP', retrieved 8 April 2018 from http://anticorrp.eu/publications/integrity-and-integrity-management-in-public-life/

Hieronymi, P. (2008), 'The Reasons of Trust', Australasian Journal of Philosophy, 86: 213-36. https://doi.org/10.1080/00048400801886496

Hill, C. A. \& O’Hara, E. A. (2006), 'A Cognitive Theory of Trust', Washington University Law Review, 84: 1717-96.

Hobbes, T. (1962), Leviathan (London, William Collins).

Hollis, M. (1998), Trust Within Reason (Cambridge, Cambridge University Press). https://doi.org/10.1017/CBO9780511612244

Holton, R. (1994), 'Deciding to Trust, Coming to Believe', Australasian Journal of Philosophy, 72(1): 63-76. https://doi.org/10.1080/00048409412345881

Huberts, L. (2014), The Integrity of Governance: What It Is, What We Know, What Is Done and Where to Go (Houndsmills, Palgrave Macmillan).

Ivashina, V. \& Scharfstein, D. (2010), 'Bank Lending During the Financial Crisis of 2008', Journal of Financial Economics, 97: 319-38. https://doi.org/10.1016/j.jfineco.2009.12.001

Jones, K. (1996), 'Trust as an Affective Attitude', Ethics, 107(1): 4-25. https://doi.org/10.1086/233694

Kantorowicz, E. H. (1957), The King's Two Bodies: A Study in Medieval Political Theology, (Princeton, NJ, Princeton University Press). 
Kaufman, A. \& Englander, E. (2005), 'A Team Production Model of Corporate Governance', Academy of Management Executive, 19(3): 9-22.

Kirby, N. (2016), 'Revising Republican Liberty: What is the Difference Between a Disinterested Gentle Giant and a Deterred Criminal?', Res Publica, 22: 369-86. https://doi.org/10.1007/s11158-015-9277-y

Kirby, N. (2018), 'An "Institution-first” Conception of Public Integrity', Building Integrity working paper. https://drive.google.com/file/d/17KhoL4yCFeYdCkL1rziG_dBYikK6hFqM/view

Klitgaard, R. (2015), Addressing Corruption Together (Paris, OECD).

Kolodny, N. (2014a), 'Rule over None I: What Justifies Democracy?', Philosophy and Public Affairs 42: 195-229. https://doi.org/10.1111/papa.12035

Kolodny, N. (2014b), 'Rule over None II: Social Equality and the Justification of Democracy', Philosophy and Public Affairs 42: 287-336. https://doi.org/10.1111/papa.12037

KPMG (2013), Integrity Survey 2013, KPMG Forensic. https://assets.kpmg.com/content/dam/kpmg/pdf/2013/08/Integrity-Survey-2013-O-201307.pdf

Kramer, M. (2008), 'Liberty and Domination', in C. \& J. (eds) Republicanism and Political Theory (Malden, MA, Blackwell), 31-57.

Kramer, R. M. (2006), Organizational Trust: A Reader (Oxford, Oxford University Press).

Kumar, M. (2018), 'Facebook Admits Public Data of its 2.2 Billion Users Has Been Compromised', The Hacker News. https://thehackernews.com/2018/04/facebook-data-privacy.html [accessed 17 June 2018].

Lagarde, C. (2014), 'Economic Inclusion and Financial Integrity; An Address to the Conference on Inclusive Capitalism', speech presented at the Conference on Inclusive Capitalism, 27 May, London.

Lang, G., (2012), 'Invigilating Republican Liberty', The Philosophical Quarterly, 62: 247, 273-93. https://doi.org/10.1111/j.1467-9213.2011.00015.x

Langtry, B. (1994), 'Stakeholders and the Moral Responsibilities of Business', Business Ethics Quarterly, 4: 431-43. https://doi.org/10.2307/3857342

Larsen, C. (2013), 'Broken Societies: Inequality, Cohesion and the Middle-class Dream', Juncture, 20(3): 193-9. https://doi.org/10.1111/j.2050-5876.2013.00753.x

LeBor, A. (1998), 'Holocaust Slaves Set to Gain Compensation', The Independent. http://www.independent.co.uk/news/holocaust-slaves-set-to-gain-compensation-1173249.html

Lenard, P. T. (2012), Trust, Democracy, and Multicultural Challenges (University Park, PA, Penn State University Press).

Lessig, L. (2013), “'Institutional Corruption” Defined', Journal of Law, Medicine and Ethics, 41: 553-55. https://doi.org/10.1111/jlme.12063

Letts, S. (2018), 'AMP Furiously Rejects Commission Open Findings, Argues Matters Should Be Dealt with by ASIC', $A B C$ News.

http://www.abc.net.au/news/2018-05-04/amp-rejects-royal-commission-findings-argues-asicshould-deal/9726802

Lewis, J. D. \& Weigert, A. (1985), 'Trust as a Social Reality', Social Forces, 63: 967-85. https://doi.org/10.2307/2578601

List, C. \& Pettit, P. (2011), Group Agency: The Possibility, Design, and Status of Corporate Agents (Oxford, Oxford University Press). https://doi.org/10.1093/acprof:oso/9780199591565.001.0001

Luhmann, N. (1979), Trust and Power, English edn (Malden, MA, Polity).

Lynam, J. (2017), 'We Messed Up Pilot Holidays, Says Ryanair', BBC News. https://www.bbc.com/news/business-41298931

Malhotra, D. (2014), 'Too Big to Trust? Managing Stakeholder Trust in Business in the Post-bail-out Economy', in J. D. Harris, B. Moriarty \& A. C. Wicks (eds) Public Trust in Business (Cambridge, Cambridge University Press), 51-85. https://doi.org/10.1017/CBO9781139152389.005 
Malhotra, D. \& Murnighan, J. K. (2002), 'The Effects of Contracts on Interpersonal Trust', Administrative Science Quarterly, 47: 534-59. https://doi.org/10.2307/3094850

Marschke, M. \& Vandergeest, P. (2016), 'Slavery Scandals: Unpacking Labour Challenges and Policy Responses Within the Off-shore Fisheries Sector', Marine Policy, 68: 39-46.

https://doi.org/10.1016/j.marpol.2016.02.009

Mathiesen, K. (2006), 'The Epistemic Features of Group Belief', Episteme, 2(3): 161-75. https://doi.org/10.3366/epi.2005.2.3.161

Mayer, C. P. (2013), Firm Commitment: Why the Corporation Is Failing Us and How to Restore Trust in It (Oxford, Oxford University Press).

Mayer, C. P. (forthcoming), Prosperity: Better Business Makes the Greater Good (Oxford, Oxford University Press).

McCraw, B. W. (2015), 'The Nature of Epistemic Trust', Social Epistemology, 29: 413-30. https://doi.org/10.1080/02691728.2014.971907

Meinhard v. Salmon, 164 N.E. 545 (N.Y. 1928).

Mitchell, R. K., Agle, B. R. \& Wood, D. J. (1997), 'Toward a Theory of Stakeholder Identification and Salience: Defining the Principle of Who and What Really Counts', The Academy of Management Review, 22: 853-86. https://doi.org/10.2307/259247

Möllering, G. (2005), 'Rational, Institutional and Active Trust : Just Do It!?’, in K. Bijlsma-Frankema \& R. Klein Woolthuis (eds) Trust Under Pressure: Empirical Investigations of Trust and Trust Building in Uncertain Circumstances (Cheltenham, Edward Elgar), 17-36. https://doi.org/10.4337/9781845427962.00006

Montefiore, A. \& Vines, D. (eds) (1999), Integrity in the Public and Private Domains (London, Routledge).

Mooney, A. (2016), 'BlackRock's Environmental Voting Record Attacked', Financial Times. https://www.ft.com/content/c49e7898-b273-11e6-9c37-5787335499a0

Moore, T. \& Mirzaei, A. (2014), 'The Impact of the Global Financial Crisis on Industry Growth', The Manchester School, 84(2): 159-80. https://doi.org/10.1111/manc.12090

Mülbert, P. O. \& Sajnovits, A. (2017), 'The Element of Trust in Financial Markets Law', German Law Journal, 18(1): 1-38.

https://static1.squarespace.com/static/56330ad3e4b0733dcc0c8495/t/588a658e579fb39b6af97293/ 1485464975011/01+PDF_Vol_18_No_01_Muelbert_Final\%281\%29.pdf

Mulder, L. B., van Dijk, E., De Cremer, D. \& Wilke, H. A. M. (2006), 'Undermining Trust and Cooperation: The Paradox of Sanctioning Systems in Social Dilemmas', Journal of Experimental Social Psychology, 42(2): 147-62. https://doi.org/10.1016/j.jesp.2005.03.002

Mungiu-Pippidi, A. (2015), The Quest for Good Governance: How Societies Develop Control of Corruption (Cambridge, Cambridge University Press). https://doi.org/10.1017/CBO9781316286937

Narayan, D. (1999), Bonds and Bridges: Social Capital and Poverty, Policy Research working paper 2167, The World Bank. Poverty Reduction and Economic Management Network: Poverty Division, Washington, DC. http://www.elgaronline.com/view/9781840646993.00013.xml>. https://doi.org/10.4337/9781781950388.00013

NBC News (2014), 'Chocolate Is a Bittersweet Way of Life in Ghana', NBC News. https://www.nbcnews.com/nightly-news/chocolate-bittersweet-way-life-ghana-n212741

Newhouse, M. E. (2014), 'Institutional Corruption: A Fiduciary Theory', Cornell Journal of Law and Public Policy, 23/3: 553-94.

Nickel, P. J. (2007), 'Trust and Obligation-Ascription', Ethical Theory and Moral Practice, 10: 309-19. https://doi.org/10.1007/s10677-007-9069-3

Offe, C. (2000), 'Democracy and Trust', Theoria: A Journal of Social and Political Theory, 96: 1-13. https://doi.org/10.3167/004058100782485693

Orr, J. (2008), 'China's Contaminated Milk Crisis Grows as Tests Show Top Dairy Firms Affected', The Guardian. http://www.theguardian.com/world/2008/sep/19/china 
Owens, D. (2006), 'A Simple Theory of Promising', Philosophical Review, 115(1): 51-77. https://doi.org/10.1215/00318108-2005-002

Owens, D. (2012), Shaping the Normative Landscape (Oxford, Oxford University Press). https://doi.org/10.1093/acprof:oso/9780199691500.001.0001

Owens, D. (2016), 'Promises and Conflicting Obligations', Journal of Ethics and Social Philosophy, 11(1): 93-108.

Parker, L. (2017), Future of the Corporation: The Voice of Business, Brunswick Group. https://www.brunswickgroup.com/future-of-the-corporation-i6306/

Petersen, M., Tilse, C. \& Cockburn, T. (2017), 'Living in a Retirement Village: Choice, Contracts \& Constraints', Journal of Housing For the Elderly, 31: 229-42. https://doi.org/10.1080/02763893.2017.1280580

Pettit, P. (1995), 'The Cunning of Trust', Philosophy and Public Affairs, 24(3): 202-25. https://doi.org/10.1111/j.1088-4963.1995.tb00029.x

Pettit, P. (1997), Republicanism: A Theory of Freedom and Government (Oxford: Oxford University Press).

Pettit, P. (1998), 'Republican Theory and Political Trust', in V. Braithwaite \& M. Levi (eds) Trust and Governance (New York, Russell Sage Foundation), 295-31.

Pettit, P. (2012), On the People's Terms: A Republican Theory and Model of Democracy (Cambridge, Cambridge University Press). https://doi.org/10.1017/CBO9781139017428

Philp, M. (1997), 'Defining Corruption', Political Studies, 45: 436-62. https://doi.org/10.1111/1467-9248.00090

Philp, M. (2007), Political Conduct (Oxford, Oxford University Press).

Pink, T. (2009), 'Promising and Obligation', Philosophical Perspectives, 23(1): 389-420. https://doi.org/10.1111/j.1520-8583.2009.00177.x

Pope, J. (1997), National Integrity Systems: The TI Source Book, 2nd edn, Transparency International \& EDI/World Bank, Washington DC.

Putnam, R. D., Leonardi, R. \& Nanetti, R. Y. (1993), Making Democracy Work: Civic Traditions in Modern Italy (Princeton, NJ, Princeton University Press).

Railton, P. (2014), 'Reliance, Trust, and Belief', Inquiry, 57(1): 122-50. https://doi.org/10.1080/0020174X.2014.858419

Raz, J. (1975), Practical Reason and Norms (Oxford, Oxford University Press).

Reid, T. (1846), The Works of Thomas Reid, D. D.: Now Fully Collected, with Selections from His Unpublished Letters (Edinburgh, Maclachlan and Stewart).

Richardson, J. (ed.), (2011), Archbold: Criminal Pleading, Evidence and Practice 2012 Full Print + Supplements, 60th edn (London, Sweet and Maxwell).

Roberts, T. (2015), 'KPMG Introduces the Art of Conversation', Raconteur. https://www.raconteur.net/technology/kpmg-introduces-the-art-of-conversation

Robinson, S. L. (1996), 'Trust and Breach of the Psychological Contract', Administrative Science Quarterly, 41: 574-99. https://doi.org/10.2307/2393868

Rothstein, B. (2011), The Quality of Government: Corruption, Social Trust, and Inequality in International Perspective (Chiacgo, Il, University of Chicago Press).

Rothstein, B. (2013), 'Corruption and Social Trust: Why the Fish Rots from the Head Down', Social Research: An International Quarterly, 80: 1009-32.

Rothstein, B. (2017), 'Solidarity, Diversity, and the Quality of Government', in K. Banting \& W. Kymlicka (eds) The Strains of Commitment: The Political Sources of Solidarity in Diverse Societies (Oxford, Oxford University Press). https://doi.org/10.1093/acprof:oso/9780198795452.001.0001

Rousseau, D. M., Sitkin, S. B., Burt, R. S. \& Camerer, C. (1998), 'Not So Different After All: A CrossDiscipline View of Trust', Academy of Management Review, 23: 393-404. https://doi.org/10.5465/amr.1998.926617 
Rousseau, J.-J. (1755), Discourse on Inequality: On the Origin and Basis of Inequality Among Men. (The Floating Press).

Ruzicka, J. \& Keating, V. C. (2015), 'Going Global: Trust Research and International Relations', Journal of Trust Research, 5(1): 8-26. https://doi.org/10.1080/21515581.2015.1009082

Scanlon, T. (1990), 'Promises and Practices', Philosophy and Public Affairs, 19(3): 199-226.

Schmitt, F. F. (1994), 'The Justification of Group Belief', in F. F. Schmitt (ed.) Socializing Epistemology: The Social Dimensions of Knowledge (Lanham. MD, Rowman and Littlefield), 253-84.

Shapiro, S. (1987), 'The Social Control of Impersonal Trust', American Journal of Sociology, 93: 623-58. https://doi.org/10.1086/228791

Shin, H. S. (2009), 'Reflections on Northern Rock: The Bank Run That Heralded the Global Financial Crisis', The Journal of Economic Perspectives, 23(1): 101-20. https://doi.org/10.1257/jep.23.1.101

Shipton, J. (2018), 'Rebuilding Trust: A Conduct Regulator's Perspective', speech presented at the AFR Banking and Wealth Summit, 5 April, Sydney. https://download.asic.gov.au/media/4691647/ james-shipton-afr-banking-and-wealth-summit-speech-5-april-2018.pdf

Simpson, T., (2017), 'The Impossibility of Republican Freedom', Philosophy and Public Affairs, 45(1): 27-53. https://doi.org/10.1111/papa.12082

Skinner, Q. (1998), Liberty Before Liberalism (Cambridge, Cambridge University Press).

Skinner, Q. (2006), 'A Third Concept of Liberty', in D. Miller (ed.) The Liberty Reader (Boulder, CO, Paradigm Publishers), 243-54.

Smith, M. N. (2010), 'Reliance', Noûs, 44(1): 135-57. https://doi.org/10.1111/j.1468-0068.2009.00734.x

Smith, T. (2017), 'Statement in Response to BlackRock Post on its Website on Climate Change', Walden Asset Management.

https://waldenassetmgmt.com/wp-content/uploads/2017/10/StatementBlackRock3-13-17.pdf [accessed 20 August 2018].

Spector, M. (2015), 'Takata U.S. Employees Saw Problems in Air-bag Tests', Wall Street Journal. https://www.wsj.com/articles/takatas-u-s-employees-flagged-reporting-issues-over-air-bags1448411043

Stout, L. A. (2011), 'Trust Behavior: The Essential Foundation of Financial Markets', in H. K. Baker \& J. R. Nofsinger (eds) Behavioral Finance (Oxford, Wiley-Blackwell), 511-22. https://doi.org/10.1002/9781118258415.ch27

Strawson, P. F. (1962), 'Freedom and Resentment', Proceedings of the British Academy, 48: 1-25.

Sztompka, P. (1998), 'Trust, Distrust and Two Paradoxes of Democracy', European Journal of Social Theory, 1(1): 19-32. https://doi.org/10.1177/136843198001001003

Taylor, R. S. (2017), Exit Left: Markets and Mobility in Republican Thought (Oxford, Oxford University Press). https://doi.org/10.1093/acprof:oso/9780198798736.001.0001

The Economist (2017), 'Big Business Sees the Promise of Clean Energy'. https://www.economist.com/business/2017/06/10/big-business-sees-the-promise-of-clean-energy

Thompson, D. F. (2005), Restoring Responsibility: Ethics in Government, Business, and Healthcare (Cambridge, Cambridge University Press).

Thomson, J. J. (1990), 'Giving One's Word', in J. J. Thompson The Realm of Rights. (Cambridge, MA, Harvard University Press), 294-321.

Tollefsen, D. P. (2006), 'Group Deliberation, Social Cohesion, and Scientific Teamwork: Is There Room for Dissent?', Episteme, 3(1-2): 37-51. https://doi.org/10.3366/epi.2006.3.1-2.37

Topham, G. (2017), 'Ryanair's Crisis Shows the True Cost of the Low-cost Revolution', The Guardian. https://www.theguardian.com/commentisfree/2017/sep/30/ryanair-low-cost-revolution-airlinecancellation-crisis

Torbisco Casals, N. (2015), 'Beyond Altruism? Globalizing Democracy in the Age of Distrust', The Monist, 98: 457-74. https://doi.org/10.1093/monist/onv024 
Trägårdh, L. (2013), 'The Historical Incubators of Trust in Sweden: From the Rule of Blood to the Rule of Law', in M. Reuter, F. Wijkstrom \& B. Uggla (eds) Trust and Organizations: Confidence Across Borders (New York, Palgrave Macmillan), 181-203. https://doi.org/10.1057/9781137368812_10

Transparency International (2018), 'Transparency International-What is Corruption?', https://www.transparency.org/what-is-corruption\#define/ [accessed 18 June 2018].

Treanor, J., Carrell, S. \& Davies, R. (2017), 'Ryanair Ordered to Tell Passengers of Options After Flights Cancelled', The Guardian.

https://www.theguardian.com/business/2017/sep/28/caa-legal-action-ryanair-nicolasturgeon-flight-cancellations

Uggla, B. K. (2013), 'The Grammar of Trust as Ethical Challenge', in M. Reuter, F. Wijkstrom \& B. K. Uggla (eds) Trust and Organizations (New York, Palgrave Macmillan), 165-79. https://doi.org/10.1057/9781137368812_3

United Nations. (2011), Guiding Principles on Business and Human Rights, HR/PUB/11/04 (New York, United Nations Office of the High Commissioner).

$<$ https://www.ohchr.org/Documents/Publications/GuidingPrinciplesBusinessHR_EN.pdf>.

Uslaner, E. M. (2002), The Moral Foundations of Trust (Cambridge, Cambridge University Press). https://doi.org/10.1017/CBO9780511614934

Uslaner, E. M. (2012), Segregation and Mistrust: Diversity, Isolation, and Social Cohesion. (Cambridge, Cambridge University Press). https://doi.org/10.1017/CBO9781139026758

Walgenbach, P. (2001), 'The Production of Distrust by Means of Producing Trust', Organization Studies, 22: 693-714. https://doi.org/10.1177/0170840601224006

Walker, D. (2009), Walker Report-A Review of Corporate Governance in UK Banks and Other Financial Industry Entities: Final Recommendations.

http://webarchive.nationalarchives.gov.uk/+/http:/www.hm-treasury.gov.uk/d/walker_review_ 261109.pdf [accessed 4 September 2018]

Walker, M. U. (2006), Moral Repair: Reconstructing Moral Relations After Wrongdoing (Cambridge, Cambridge University Press). https://doi.org/10.1017/CBO9780511618024

Wallace, R. J. (2006), Normativity and the Will: Selected Essays on Moral Psychology and Practical Reason (Oxford, Clarendon Press).

Wang, U. (2014), 'Why Target's Anti-union Video is No Joke'. The Guardian. http://www.theguardian.com/sustainable-business/target-anti-union-video-cheesy-but-effective

Wellings, R. (2016), Without Delay: Getting Britain's Railways Moving, discussion paper 69, The Paragon Initiative, Institute of Economic Affairs, London.

https://iea.org.uk/wp-content/uploads/2016/07/Without\%20delay\%20Getting\%20Britain's\%20 Railways\%20Moving_0.pdf

Wheatley, M. (2015), 'Debating Trust and Confidence in Banking', speech presented at the ResPublica Vocational Banking event, 28 May, London.

https://www.fca.org.uk/news/speeches/debating-trust-and-confidence-banking [accessed 26 August 2018].

White, S. (2017), 'Japanese Firms Avoiding Price Hikes Now but Sentiment is Changing', Reuters. https://www.reuters.com/article/us-japan-economy-boj/bojs-nakaso-companies-avoiding-higherlabor-costs-by-reducing-hours-idUSKBN1AB073

Whitehouse, S. \& Stinnett, M. W. (2017), Captured: The Corporate Infiltration of American Democracy (New York, The New Press).

Williamson, O. E. (1993), 'Calculativeness, Trust, and Economic Organization', The Journal of Law and Economics, 36(1): 453-86. https://doi.org/10.1086/467284

Winter, J. W. (2011), 'Corporate Governance Going Astray: Executive Remuneration Built to Fail', in Festschrift for Professor Klaus Hopt (Berlin, Walter de Gruyter), 1521-35. https://papers.ssrn.com/abstract $=1792483$ 
Zaheer, A., McEvily, B. \& Perrone, V. (1998), 'Does Trust Matter? Exploring the Effects of Interorganizational and Interpersonal Trust on Performance', Organization Science, 9(2): 141-59. https://doi.org/10.1287/orsc.9.2.141

Zucker, L. (1986), 'Production of Trust: Institutional Sources of Economic Structure, 1840-1920', Research in Organizational Behavior, 8: 53-111.

\section{Notes about authors}

Aisling Crean BA(Hons) MLitt MSc PhD teaches on the Master of Public Policy at the Blavatnik School of Government, University of Oxford.

aisling.crean@gmail.com

Nikolas Kirby BA (Hons) LLB (Hons) BPhil Dphil is Director of the Building Integrity Programme and Research Fellow in Philosophy and Public Policy, Blavatnik School of Government, University of Oxford.

nikolas.kirby@bsg.ox.ac.uk

Andrew J Kirton BA (Hons) MRes PhD is a Lecturer in Inter-Disciplinary Ethics Applied Centre, University of Leeds.

a.kirton@leeds.ac.uk

To cite the article: Nikolas Kirby, Andrew Kirton and Aisling Crean (2018), 'Do corporations have a duty to be trustworth?', Journal of the British Academy, 6(s1): 75-129.

DOI https://doi.org/10.5871/jba/006s1.075

This article is licensed under a

Creative Commons Attribution-NonCommercial-NoDerivs 4.0 Unported License.

Journal of the British Academy (ISSN 2052-7217) is published by

The British Academy - the national academy for the humanities and social sciences.

10-11 Carlton House Terrace, London, SW1Y 5AH

www.britac.ac.uk 
